\title{
An Assessment of Environmental Health and Safety Issues \\ Associated with the \\ Commercialization of \\ Unconventional Gas Recovery: \\ Tight Western Sands
}

Project Manager

E. F. Riedel

February 1980

Prepared for the U.S. Department of Energy

Assistant Secretary for Environment

Office of Environmental Assessments

Technology Assessments Division

under Contract DE-AC06-76RLO 1830

Pacific Northwest Laboratory

Operated for the U.S. Department of Energy

by Battelle Memorial Institute 
This report was prepared as an account of work sponsored by the United States Government. Neither the United States nor the Department of Energy, nor any of their employees, nor any of their contractors. subcontractors. or their employees, makes any warranty, express or implied, or assumes any legal liability or responsibility for the accuracy. completeness or usefulness of any information, apparatus. product or process disclosed, or represents that its use would not infringe privately owned rights.

The views, opinions and conclusions contained in this report are those of the contractor and do not necessarily represent those of the United States Government or the United States Department of Energy.

\author{
PACIFIC NORTHWEST LABORATORY \\ operated by \\ BATTELLE \\ for the \\ UNITED STATES DEPARTMENT OF ENERGY \\ Under Contract DE-AC06-76RLO 1830
}
Printed in the United States of America Available from
National Technical Information Service Lnited States Department of Commerce 5285 Port Royal Road Springfield, Virginia 22151

Price: Printed Copy 5 $\therefore$ Microtiche $\$ 3.00$

NTIS

- Pages Selling Price

$\begin{array}{ll}001-025 & \$ 4.00 \\ 026-050 & \$ 4.50 \\ 051-075 & \$ 5.25 \\ 076-100 & \$ 6.00 \\ 101-125 & \$ 6.50 \\ 126-150 & \$ 7.25 \\ 151-175 & \$ 8.00 \\ 176-200 & \$ 9.00 \\ 201-225 & \$ 9.25 \\ 226-250 & \$ 9.50 \\ 251-275 & \$ 10.75 \\ 276-300 & \$ 11.00\end{array}$




\section{9}

AN ASSESSMENT OF ENVIRONMENTAL

HEALTH AND SAFETY ISSUES ASSOCIATED

WITH THE COMMERCIALIZATION OF

UNCONVENTIONAL GAS RECOVERY:

TIGHT WESTERN SANDS

PNL Project Manager

E. F. Riedel

Authors

E. F. Riedel

C. E. Cowan

T. J. McLaughl in

DOE Project Manager

G. J. Rotariu

Office of Environmental Assessments

Technology Assessments Division

February 1980

Prepared for

the U.S. Department of Energy

under Contract DE-AC06-76RLO 1830

Pacific Northwest Laboratory

Richland, Washington 99352 


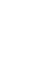




\section{CONTENTS}

1.0 INTRODUCTION

2.0 RESOURCE DESCRIPTION AND RECOVERY TECHNIQUES . . . . . . 2-1

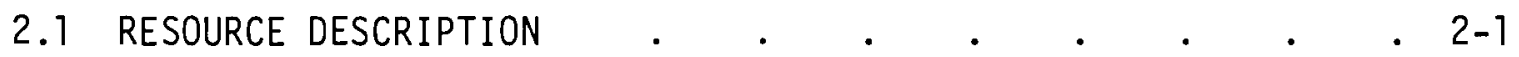

2.2 CURRENT RECOVERY TECHNIQUES . . . . . . . . . . 2-4

3.0 ADVANCED RECOVERY TECHNIQUES . . . . . . . . . . . . . $3-1$

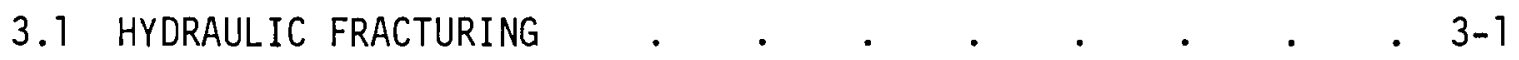

3.1.1 Fracturing Fluids . . . . . . . . . 3-2

3.1.2 Massive Hydraulic Fracturing . . . . . 3-3

3.1.3 Foam Fracturing . . . . . . . . . 3-7

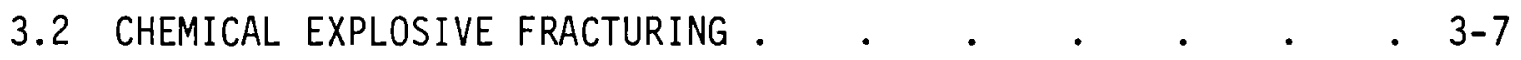

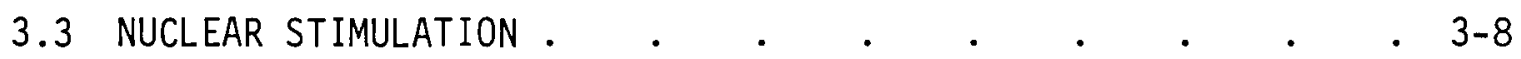

3.3.1 Project Gasbuggy . . . . . . . . . . 3-8

3.3 .2 Project Rulison . . . . . . . . . 3-9

3.3.3 Project Rio Blanco . . . . . . . 3-10

3.3 .4 Conclusion .

4.0 BARRIERS TO COMMERCIAL PRODUCTION . . . . . . . . 4-1

4.1 ECONOMICS. $. \quad . \quad . \quad . \quad . \quad . \quad . \quad . \quad . \quad$. $4-1$

4.2 WATER RESOURCES . . . . . . . . . . . . 4-1

4.3 RISK CAPITAL AVAILABILITY . . . . . . . . 4-5

5.0 ASSESSMENT OF ENVIRONMENTAL HEALTH AND SAFETY IMPACTS . . . 5-

5.1 ENVIRONMENTAL ASSESSMENT . . . . . . . . . . . 5-1

5.1.1 Exploration . . . . . . . . . . 5-1

5.1.2 Field Development . . . . . . . . 5-3 


\section{1 .3 Production . . . . . . . . . 5-9 \\ 5.1 .4 Abandonment . . . . . . . . . 5-9}

5.2 HEALTH AND SAFETY ASSESSMENT . . . . . . . . 5-9

6.0 CONCLUSIONS AND RECOMMENDATIONS . . . . . . . . . 6-1

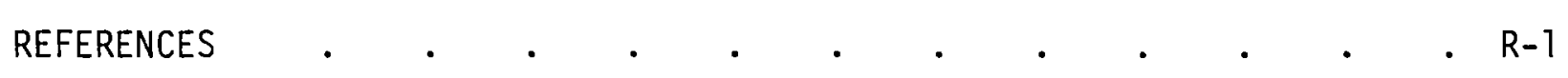

APPENDIX A - PETROLEUM FIELD TECHNOLOGY . . . . . . . . . A-1 


\section{FIGURES}

2.1 Tight Gas Sand Basins . . . . . . . . . . . . . 2-2

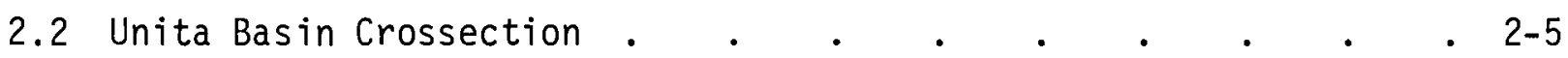

2.3 Piceance Basin Crossection . . . . . . . . . . . . 2-6

2.4 Greater Green River Basin Crossection . . . . . . . 2-7

2.5 Location of DOE's Cost Shared Projects . . . . . . 2-10

3.1 Equipment Types and Location During an MHF Job . . . . 3-5

3.2 Multistage Massive Hydraulic Fracturing Job . . . . . 3-6

3.3 Locations of the Three Nuclear Stimulation Tests . . . . 3-9

5.1 Relationship Between CO Exposure (hours and concentration)

Versus Health Effects . . . . . . . . . 5-11

\section{$\underline{\text { TABLES }}$}

2.1 Reservoir Characteristics of the Tight Gas Formation . . . 2-3

2.2 DOE's Cost Shared Western Gas Field Projects . . . . . . 2-9

4.1 Average and Extreme Low Stream Flows for Potentially Usable
Streams by UGR Basin . . . . . . . . . . . . . . $4-3$

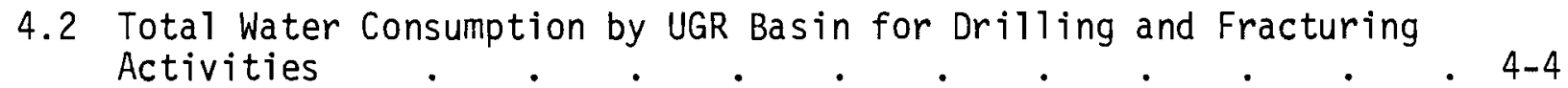

5.1 Potential Environmental Impacts from Gas Field Development . 5-2

5.2 Emissions from One $1100 \mathrm{hp}$ Diesel Engine . . . . . . 5-6

5.3 Emissions from a Typical Stimulation Job • • • • • • 5-8 


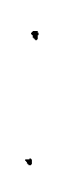




\subsection{INTRODUCTION}

The United States is in the midst of an energy crisis which is becoming increasingly more serious. The problems, which became readily apparent with the Arabian 0il Embargo of 1973, have worsened with the loss of production of oil in Iran coupled with large price increases by the Organization of Petroleum Exporting Countries (OPEC). These problems have emphasized the need for the United States to develop and implement new techniques for the identification and increased recoverability of our fossil energy resources.

Recovering natural gas from unconventional sources is of major importance in the overall energy program. There are currentiy four identified sources of unconventional natural gas. The Department of Energy (DOE) has initiated four projects, directed at each of these resource areas:

Sources

Tight gas sands

Methane associated with coal seams

Devonian age shales

Methane contained in geopressured aquifers

$\frac{\text { Projects }}{\text { Western gas sands }}$
Methane from coal
Eastern gas shales
Geopressured aquifers

On Ju1y 16, 1979, President Carter proposed a program which would have a major impact on the recovery of gas from unconventional sources. The president asked Congress to create an independent Energy Security Corporation which wi 11 make investments in the production of synthetic fuels from coal, biomass, peat and oil shale, and in the development of reserves of unconventional natural gas. Before these unconventional natural gas sources can add significantly to our nation's supply, the public health and safety, environmental, social, economic, and legal/political consequences and constraints that may be associated with these technologies must be identified and examined. This document presents results of a study to identify and evaluate potential public health and safety problems and the potential environmental impacts from recovery of natural gas from Tight Western Sands. A brief discussion of economic and technical constraints to development of this resource is also presented to place the environmental and safety issues in perspective. This assessment is being conducted 
for the Technology Assessments Division, Office of Environmental Assessments, under the Assistant Secretary of the Environment in the U.S. Department of Energy. This division is responsible for assessing all potential environmental, health and safety consequences and constraints of any new technology for producing energy. These assessments provide information for a number of different uses: Environmental Readiness Documents (ERD's), Environmental Assessments (EA's), Environmental Impact Statements (EIS's), Environmental Development Plans (EDP's), and Project Environmental Plans (PEP's). In addition, the results may be used in the development of policy and the formulation and implementation of Research and Development (R\&D) plans.

This document presents a description of the resource base, recovery techniques and possible environmental effects associated with tight gas sands. Assessments of the other unconventional gas resources will be the subject of future reports. 


\subsection{RESOURCE DESCRIPTION AND RECOVERY TECHNIQUES}

The principal distinction between gas from unconventional sources and conventional gas is related to the time required for commercial development. Our unconventional resources will become commercially viable when existing economic, environmental, technological, legal and political barriers are overcome. The Department of Energy has identified three unconventional gas resources for commercialization (Ham and Dewey 1978). These resources are:

- Tight gas sands (a)

- Coalbed methane near local (i.e., non-pipeline) markets

- Devonian shales.

Two additional unconventional resources were judged as too uncertain for near-term commercialization. These resources are geopressured aquifers of the Gulf coast and coalbed methane (other than for local markets). The resources and current recovery techniques associated with Tight Western Sands are described below. Future work in the project will discuss the other technologies identified for near-term commercialization of gas from unconventional sources.

\subsection{RESOURCE DESCRIPTION}

Large quantities of natural gas exist in a number of sedimentary basins containing sands of low permeability (so called tight formations). The flow rate of the natural gas in these formations is normally low enough to preclude commercial development of these basins. The basins which contain these formations stretch westward from the Arkoma Basin of Oklahoma-Arkansas to the Snake River Downwarp of Idaho; and northward from the Cotton Valley Trend of TexasLouisiana to the Northern Great Plains Providence of Montana-Canada. Figure 2.1 shows the geographical location of these basins and Table 2.1 summarizes the reservoir characteristics of the tight gas formations. Recently there has been a surge of new activity in some of these basins which was spurred perhaps by the

(a) Throughout this report the terms Tight Western Sands is used synonymously with Tight Gas Sands. 


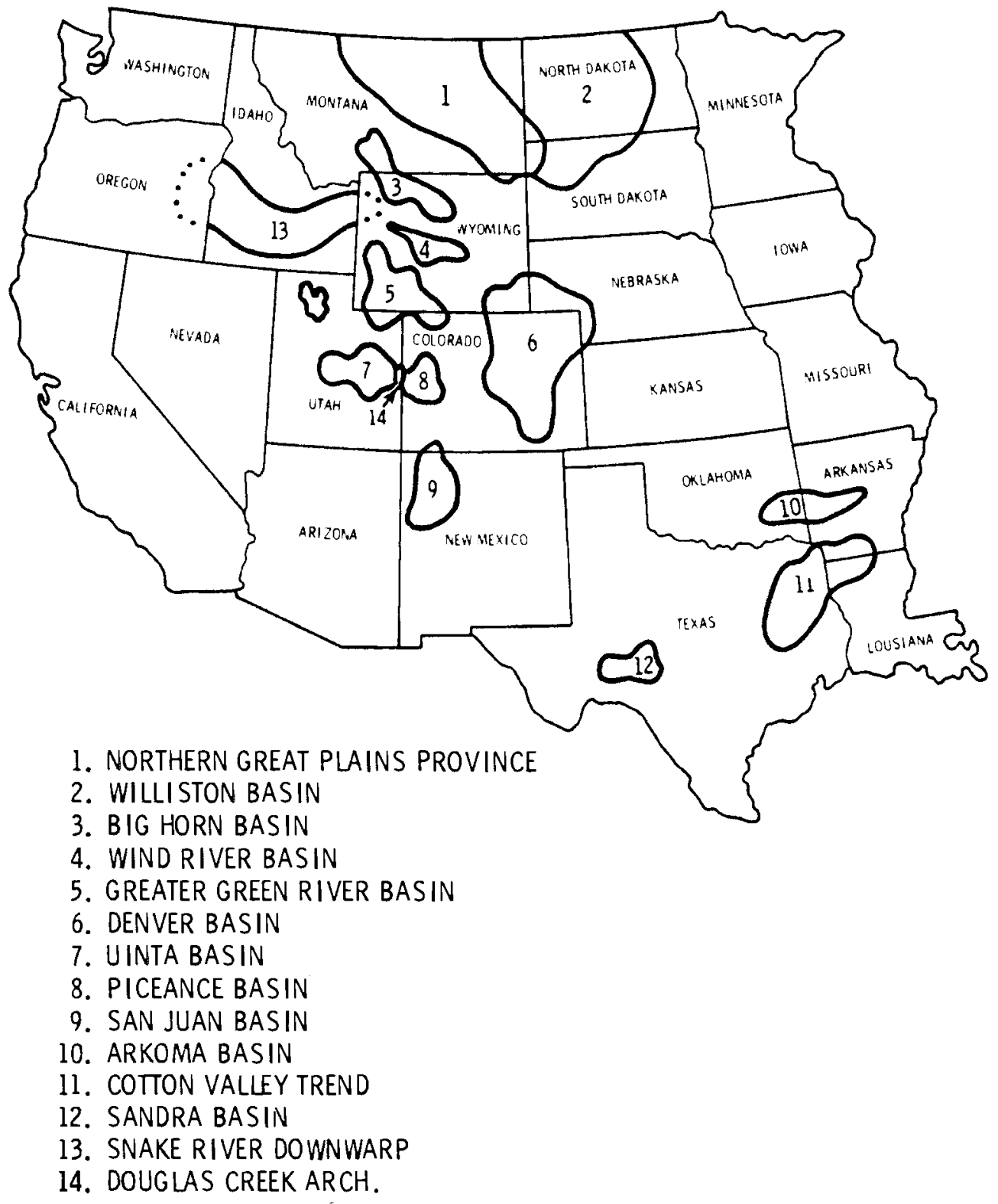

FIGURE 2.1. Tight Gas Sand Basins (Western Gas Sands Project 1978) 
TABLE 2.1. Reservoir Characteristics of the Tight Gas Formation (Kuusknaa et al. 1978)

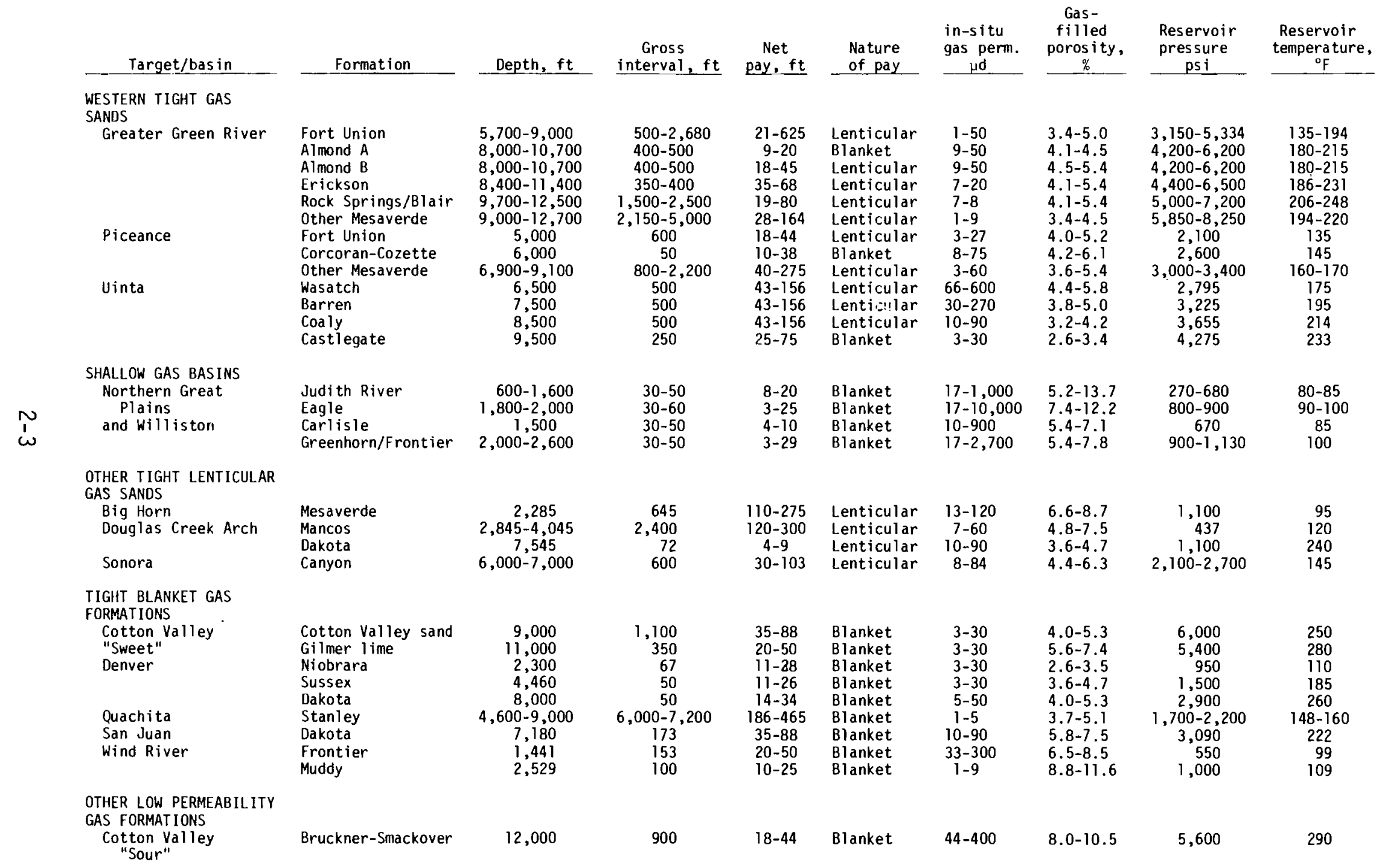


higher price of natural gas that resulted from the National Gas Pricing Act (Natural Gas Policy Act 1978).

A 1973 Federal Power Commission (FPC) Report identified three basins, the Uinta Basin, the Piceance Basin and the Greater Green River Basin, as having good potential for additional natural gas production. Diagrammatic cross sections of each of these basins are shown in Figures 2.2, 2.3 and 2.4. These basins contain an estimated 600 TCF of gas. The FPC study estimates that up to 231.9 TCF of gas might be recoverable from these basins. This would provide approximately an 11.5 year supply of gas for the United States at the current rate of usage.

\subsection{CURRENT RECOVERY TECHNIQUES}

All of the basins described in Section 2.1 have had at least exploratory (wildcat) drilling. However, the extent of the resource is uncertain because the number of wells drilled and placed in production have been insufficient to provide the necessary production history. Also the rate of production is so low that good data are not available on change-in-pressure versus time. This information is needed for proper reservoir evaluation of these individual wells and reservoirs.

All these basins have a limited flow capacity due to their extremely low permeability (normally less than $1 \mathrm{mD}{ }^{(a)}$ ). The producing zones found within these basins are quite discontinuous. These producing zones also differ greatly from basin to basin. Lack of continuity of these gas zones, which is due partly to their lenticularity (lens-like nature), has the effect of giving a small area of drainage. The more common type of petroleum reservoir is a thicker blanket type, which is more continuous.

These Tight Western Basins are now considered non-commercial because of their low gas production rates. The major factors that affect the gas production rate

(a) $1 \mathrm{mD}$ is one miliDarcy. One Darcy is defined to be the permeability of a porous rock of unit cross section area, if water (or some other fluid of one centipoise viscosity) flowing at one cubic centimeter per second causes a drop in pressure of one atmosphere per centimeter of distance traveled. 


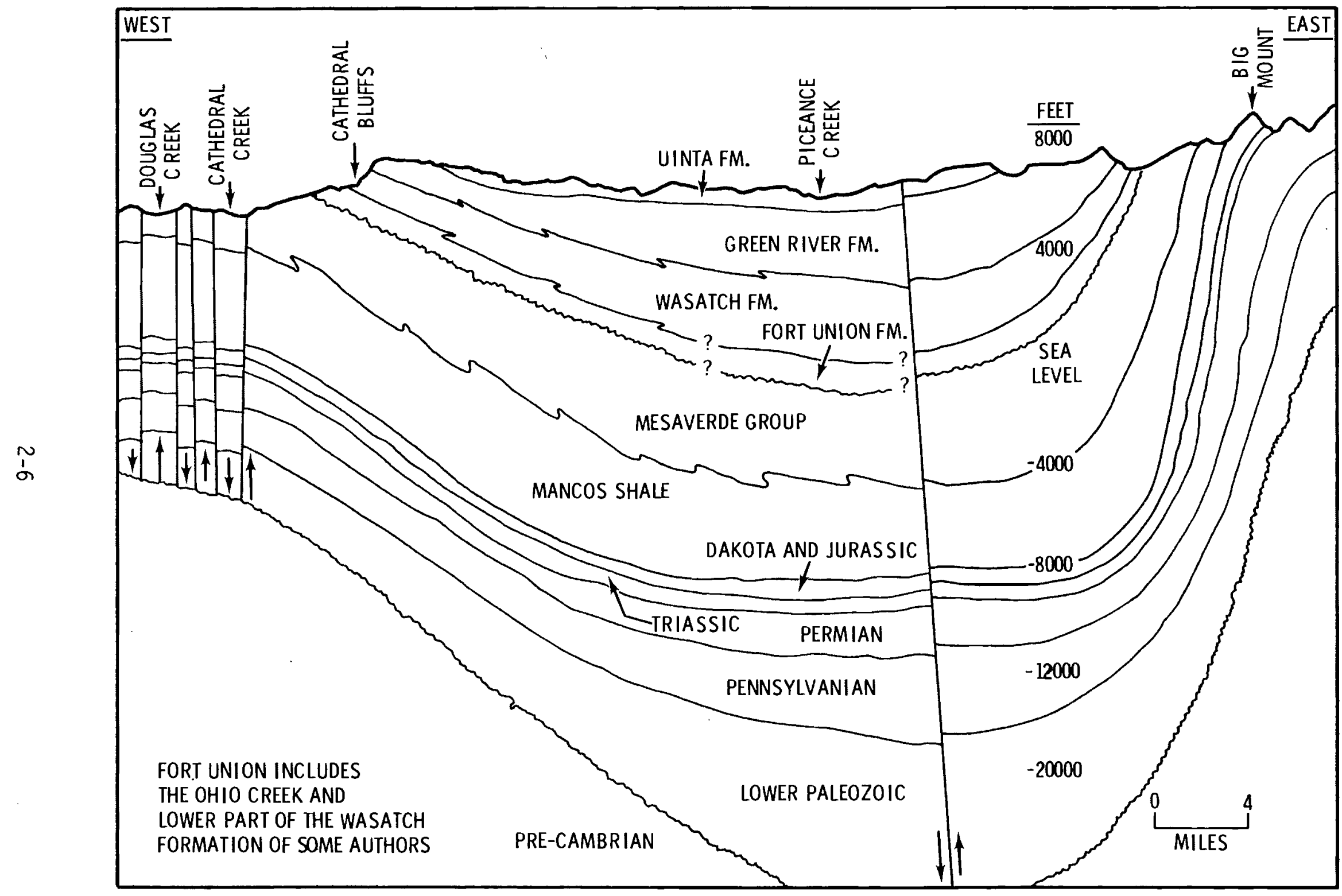

FIGURE 2.3. Piceance Basin Crossection (Appledoon and Mann 1977) 


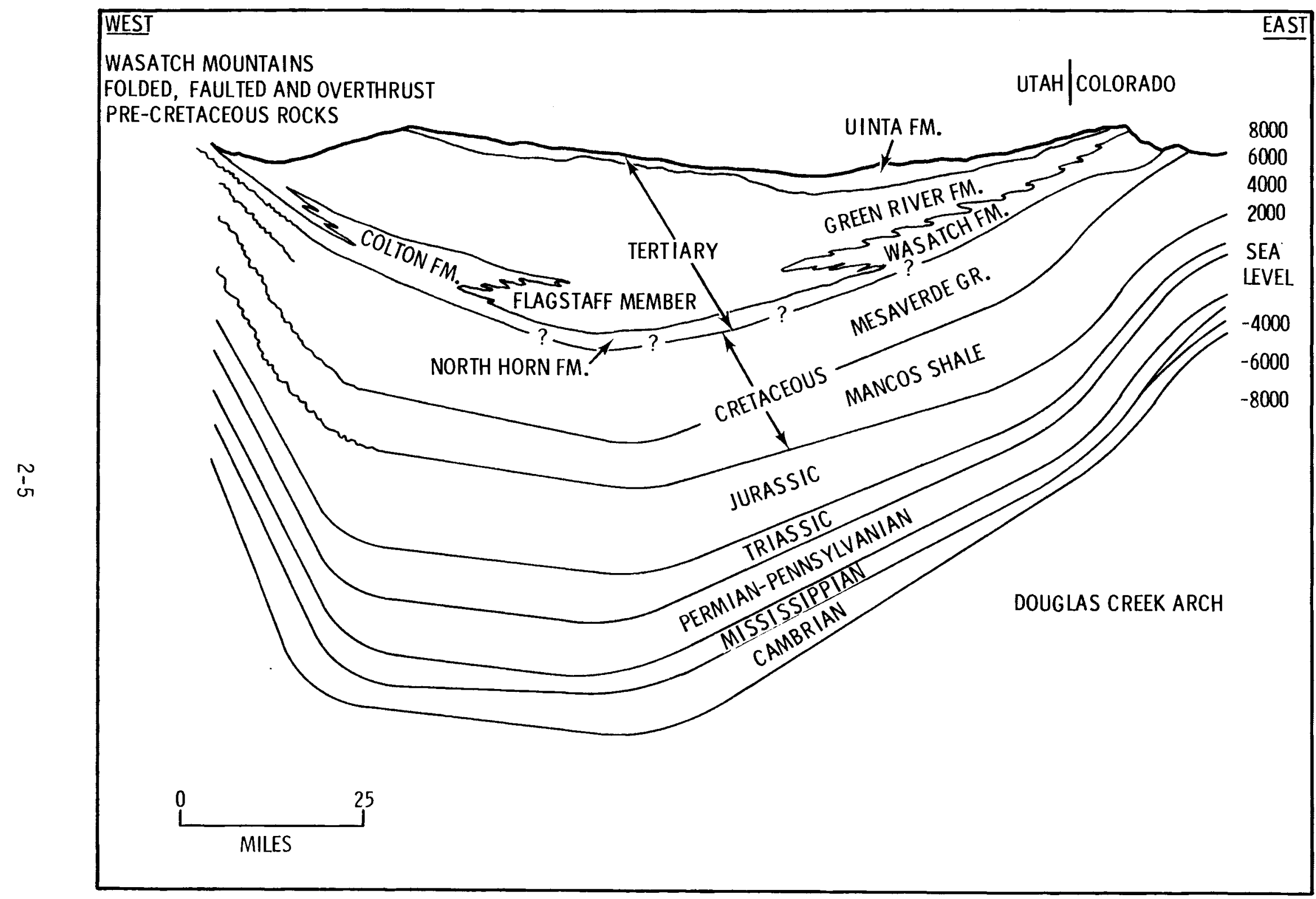

FIGURE 2.2. Uinta Basin Crossection (Knutson and Boardman 1978) 


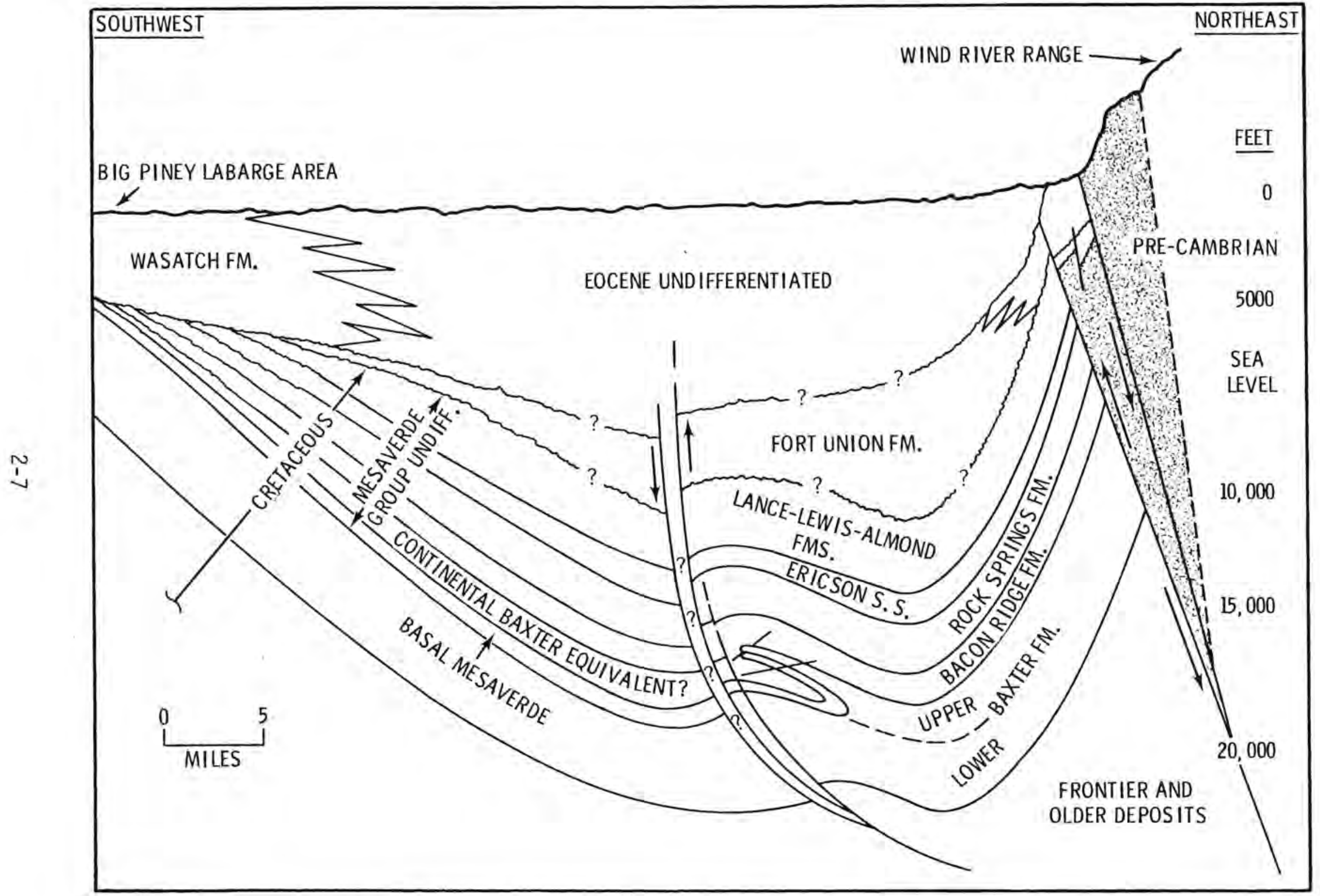

FIGURE 2.4. Greater Green River Basin Crossection (Randolph 1976) 
are: 1) the in-place gas permeability, 2) the reservoir thickness, 3) the net gas pore volume, and 4) the in-situ water saturation. As the (immobile) water saturation increases, with other factors being equal, there is a marked decrease in the relative permeability of the gas. The in-situ water saturation may only be determined from a drilled well, and it will vary over the field.

The Department of Energy has summarized the major barriers to commercialization of these basins as:

- gas price

- uncertain well performance

- lack of reservoir engineering data

- potential limitation of risk and/or development capital

- pipeline delays.

DOE has sponsored a number of stimulation tests in these basins as well as in the Cotton Valley Trend, the Sonora Basin, and in the Fort Worth Bas in which are all in Texas. DOE is supporting field projects in the areas shown in Table 2.2. The geographical locations of these projects are shown in Figure 2.5. (a)

The rig count for Wyoming shows there has been a recent surge of activity in the Greater Green River Basin, possibly due to the recently enacted Natural Gas Policy Act of 1978 (NGPA).

The Administration proposed a $\$ .50 /$ million cubic feet (Mcf) tax credit for all unconventional gas production. (The tax credit would phase out at a world oil price equivalent of $\$ 28$ per barrel.) The President, through the Department of Energy, will ask the Federal Energy Regulatory Commission to establish a special incentive price for the unconventional gas. These factors indicate that commercial production of natural gas from unconventional sources will become an important contributor to our energy resources in the near future.

These initial efforts are designed to lead eventualiy to commercial ventures. The goal of the commercialization effort is to yield production of

(a) Compiled from Volumes 1 through 18 of Enhanced $0 i 1$ and Gas Recovery and Improved Drilling Technology, U.S. DOE Division of Fossil Fuel Extraction, Bartiesvilie Energy Technology Center. 
from three to six trillion cubic feet (TCf) of natural gas per year. For comparison, the U.S. currently consumes approximately 20 Tcf of natural gas every year.

\section{TABLE 2.2. DOE's Cost Shared Western Gas Field Projects}

\begin{tabular}{|c|c|c|c|c|c|c|}
\hline Project & Contractor & Date & $\begin{array}{r}\text { Anticipated } \\
\text { Completion } \\
\end{array}$ & $\begin{array}{l}\text { Gov't } \$ \\
\text { Millions }\end{array}$ & $\begin{array}{c}\text { Contractor } \\
\text { Cost } \\
\end{array}$ & $\begin{array}{l}\text { Total \$ } \\
\text { Million } \\
\end{array}$ \\
\hline $\begin{array}{l}\text { Sutton County, Texas } \\
\text { Canyon Sand Explosive } \\
\text { Fracturing Project }\end{array}$ & $\begin{array}{l}\text { Petroleum Tech. } \\
\text { Corp. } \\
\text { Redmond, Washington }\end{array}$ & July 1,1976 & Dec. 1979 & 0.75 & -- & 0.75 \\
\hline $\begin{array}{l}\text { Turtle Shell Unit } \\
\text { Uintah County, Utah } \\
\text { Massive Hydraulic } \\
\text { Fracturing Demonstration }\end{array}$ & $\begin{array}{l}\text { Texas American } 0 i 1 \\
\text { Corp. \& Western } \\
\text { 0il Shale Corp. } \\
\text { Midland, Texas }\end{array}$ & July 1,1976 & Sept. 30,1977 & 0.065 & 1.066 & 1.131 \\
\hline $\begin{array}{l}\text { Rulison Field, } \\
\text { Colorado Massive } \\
\text { Hydraulic Fracturing } \\
\text { Demonstration }\end{array}$ & $\begin{array}{l}\text { Austral } 0 i 1 \\
\text { Company } \\
\text { Houston, Texas }\end{array}$ & June 15,1976 & Dec. 15,1976 & 0.334 & 0.599 & 0.933 \\
\hline $\begin{array}{l}\text { Wise County, Texas } \\
\text { Massive Hydraulic } \\
\text { Fracturing Demonstration }\end{array}$ & $\begin{array}{l}\text { Dallas Production } \\
\text { Inc. } \\
\text { Dallas, Texas }\end{array}$ & Aug. 1, 1976 & Dec. 31,1976 & 0.150 & 0.178 & 0.328 \\
\hline $\begin{array}{l}\text { Green River Basin, } \\
\text { Sublette County, Wyoming } \\
\text { Massive Hydraulic } \\
\text { Fracturing Field } \\
\text { Demonstration }\end{array}$ & $\begin{array}{l}\text { El Paso Natural } \\
\text { Gas Co., } \\
\text { El Paso, Texas }\end{array}$ & Sept. 19, 1975 & Oct. 1978 & 1.608 & -- & 1.608 \\
\hline $\begin{array}{l}\text { Mineral Wells, Texas } \\
\text { Chemical Explosive } \\
\text { Fracturing Field } \\
\text { Demonstration }\end{array}$ & $\begin{array}{l}\text { Tally Frac Corp., } \\
\text { Mesa, Arizona }\end{array}$ & June 24,1974 & Completed & 0.131 & - & 0.131 \\
\hline $\begin{array}{l}\text { Rio Blanco County, Colorado } \\
\text { Hydraulic Fracturing } \\
\text { Experiment }\end{array}$ & $\begin{array}{l}\text { CER Corp. } \\
\text { Las Vegas, Nevada }\end{array}$ & June 17,1974 & & 1.975 & 1.63 & 3.005 \\
\hline $\begin{array}{l}\text { Naturai Buttes, Unit } \\
\text { Uintah County, Utah } \\
\text { Massive Hydrauiic } \\
\text { Fracturing Demonstration }\end{array}$ & $\begin{array}{l}\text { Gas Producing } \\
\text { Enterprises, Inc. } \\
\text { Subsidiary of } \\
\text { Coastal States Gas } \\
\text { Houston, Texas }\end{array}$ & July 1,1976 & Sept. 30,1979 & 2.827 & 4.932 & 7.759 \\
\hline $\begin{array}{l}\text { Limestone County, Texas } \\
\text { Massive Hydraulic } \\
\text { Fracturing Demonstration }\end{array}$ & $\begin{array}{l}\text { Mitchell Energy } \\
\text { Corp. } \\
\text { Houston, Texas }\end{array}$ & March 15, 1978 & Apr. 30,1979 & 0.553 & $1.07 \mathrm{H}$ & 1.628 \\
\hline $\begin{array}{l}\text { Piceance Creek Field } \\
\text { Colorado. Massive Hydraulic } \\
\text { Fracturing Demonstration }\end{array}$ & $\begin{array}{l}\text { Mobil Research } \\
\text { and Development } \\
\text { Dallas, Texas }\end{array}$ & July 1, 1976 & June 1,1979 & 2.51 & 3.967 & 6.477 \\
\hline $\begin{array}{l}\text { Sand Ridge Area, } \\
\text { Uintah County, Utah } \\
\text { Massive Hydrauilic } \\
\text { Fracturing Demonstration }\end{array}$ & $\begin{array}{l}\text { Pacific Transmission } \\
\text { Supply Company } \\
\text { San Francisco, } \\
\text { California }\end{array}$ & Sept. 11, 1976 & Jan. 31, 1979 & 0.464 & 0.878 & 1.342 \\
\hline $\begin{array}{l}\text { Rio Blanco County, Colorado } \\
\text { Massive Hydraulic } \\
\text { Fracturing Demonstration }\end{array}$ & $\begin{array}{l}\text { Rio Blanco } \\
\text { Natural Gas } \\
\text { Company } \\
\text { Colorado }\end{array}$ & Aug. 1, 1976 & Mar. 31,1978 & 0.410 & 0.593 & 1.003 \\
\hline
\end{tabular}




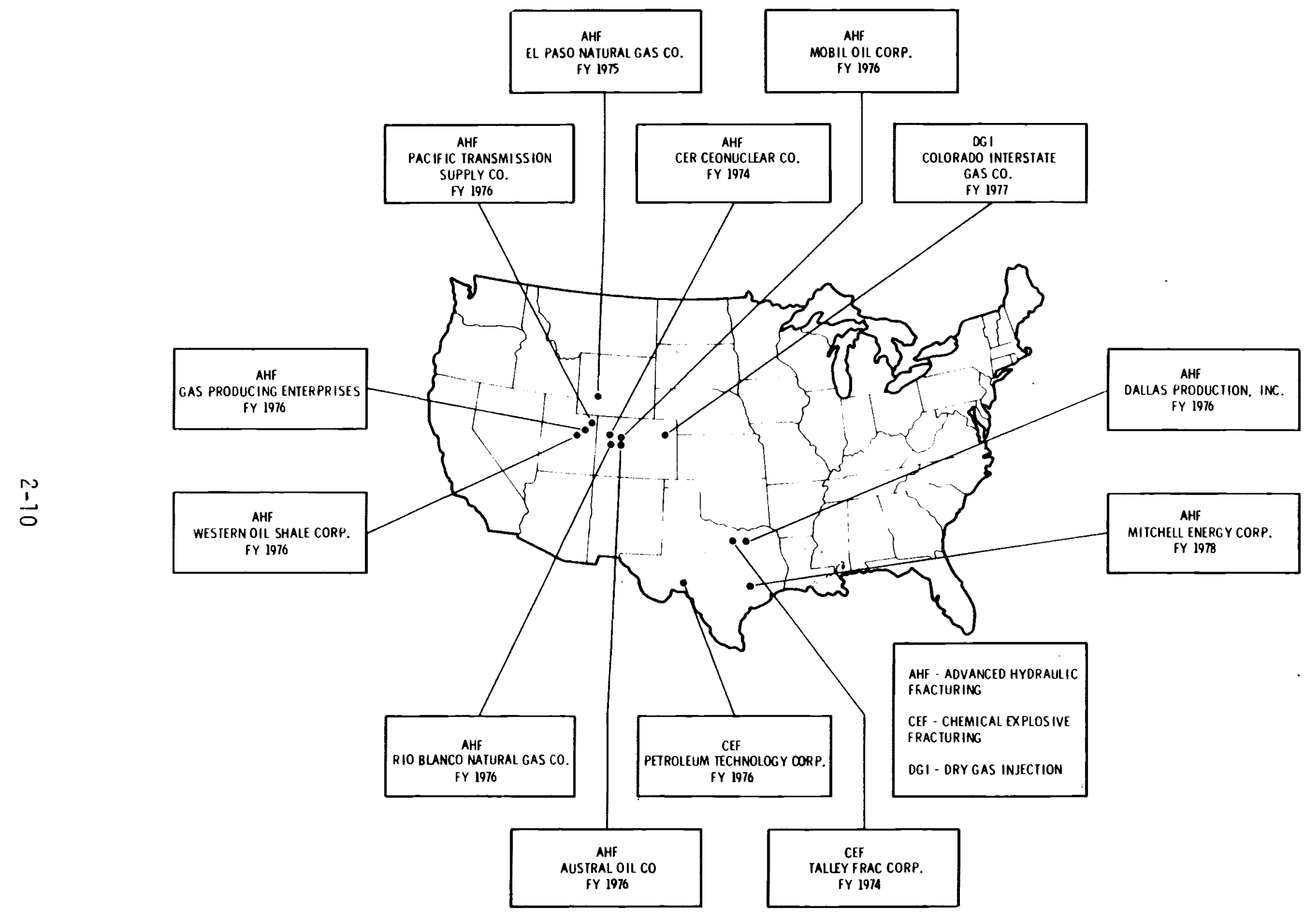

FIGURE 2.5. Location of DOE's Cost Shared Projects 


\subsection{ADVANCED RECOVERY TECHNIQUES}

The Tight Western Sands are considered non-commercial at this time because of their limited flow capacity which is responsible for low gas production rates. One way to increase flow capacity in a reservoir is to increase the effective wellbore drainage volume using some type of fracturing technique to open a large fracture network. Another method is to physically increase the wellbore radius via nuclear stimulation. Techniques under development to produce commercial quantities of gas from Tight Western Sands include a number of advanced fracturing processes which have been used and are being used currently. Among the many methods which have been tried at least once in Tight Western Sands are:

- Advanced hydraulic fracturing

- Chemical explosive fracturing

- Nuclear stimulation

Each of these methods is discussed below. A fourth method, (deviated wells and earth fracture systems) is potentially applicable to Tight Western Sands, but has only been associated with the resource of Devonian shales. This technique will be discussed in a future report on Devonian shale.

\subsection{HYDRAULIC FRACTURING}

Hydraulic fracturing is a method of well stimulation which has been in use since 1947 (Howard and Fast 1970). It is a process of creating a fracture or a system of fractures in a reservoir via the injection of a fluid under pressure. The fracture is then kept open (propped) by a propping agent which has been added to the fracturing fluid.

The first hydraulic fracturing job was in the Hugoton gas field in western Kansas in 1947. This job was on the Klepper No. 1 well located in Grand County (Howard and Fast 1970, p. 8). Four separate treatments were used, one for each of the three perforated zones and one on the bottom open hole section. It was concluded this process could not compete economically 
with acidizing in this 1 imestone reservoir (however, since 1966 hydraulic fracturing has been the primary method used). Hydraulic fracturing is normally used to accomplish five basic jobs:

- overcome wellbore damage

- create deep-penetrating reservoir fractures

- aid in secondary recovery operations

- assist in the disposal of oilfield brines

- provide standard completion method for gas well.

There are two types of advanced hydraulic fracturing methods: 1) Massive hydraulic fracturing (described in Section 3.1.2); and 2) Foam fracturing (described in Section 3.1.3). Since both of these fracturing methods may use a common fluid, the actual fracturing fluids will be discussed in Section 3.1.1.

\subsubsection{Fracturing Fluids}

Fracture fluids are designed based on the desired fluid return rates, sensitivity of the formation, fracturing ability and economics.

Fracturing fluids may be divided into three categories: aqueous-base, oil-base, and mixed-base. This division is based upon the main component of the fluid.

The two aqueous-based fluids are water and hydrochloric acid. The aqueous based fluids are usually gelled by the addition of a polymeric species. These thickened fluids have low fluid loss and are better able to carry the proppant material. Aqueous-based fluids are much safer to use than the oil-based fluids because of the explosion potential of oil-based fluids; however, they can not be used in formations which contain clays which are highly water sensitive.

0i1-based fracturing fluids may consist of various cuts of refined products or they may be a product straight from a lease. The lighter petroleum cuts such as distillate, kerosene, or diesel oil are most often used in gas wells because they return more readily from the reservoir. 0il-based fluids are more expensive than the aqueous based fluids and are normally only used in reservoirs that are highly sensitive to water. 
Mixed-base fluids are emulsions of varying composition (Howard and Fast, 1970, Frick 1972, Ch. 47). The mixed-base emulsion fluids consist of a mixture of $0 i 1$ and either water or acid. Some type of surface active agent (surfactant) is added to cause the stabilization of the mixture. Emulsion-base fluids have good proppant carrying characteristics (due to their high viscosity) and have low fluid loss. These fluids may be used in formations which have water sensitivity. Due to their oil content, emulsion-base fluids are most expensive and are used mostly in small fracturing jobs.

There are a number of chemicals which may be added to fracturing fluids for a number of different reasons (Howard and Fast 1970, Frick 1972). Specifically, the chemicals used depend on the geochemistry of the specific formation. These chemicals are:

- thickening or gelling agents

- fluid loss control agents

- friction prevention agents

- demulsifying agents

- surfactants

- swelling control agents

- emulsifying agents

- sequestering agents

- gel breakers

- inhibitors.

\subsubsection{Massive Hydraul ic Fracturing}

There is no clear definition of what constitutes a massive hydraulic fracturing (MHF) job. There is a constant gradation from very small jobs of a few hundred gallons of fluid to jobs that use more than 2.8 million pounds of proppant and more than a million gallons of fluid. The proppant is added to the fracture fluid to hold or prop the fracture open after the fracturing job is completed. A definition of massive hydraulic fracturing, used by DOE, is any fracture treatment in excess of 300,000 gallons of liquid. Some operators consider any job over 50,000 gallons to be massive. 
A typical hydraulic fracturing job consists of injecting a fracturing fluid and a proppant. The fracturing fluid used may be water-based, oilbased, or mixed-based. The proppant may be sand (usually Ottowa sand), glass beads, sintered bauxite, oxide ceramic proppants, resin coated sand, walnut shells, or zirconium oxide beads. Frequently, different types and sizes of proppants are used in the same treatment. The stages in a massive hydraulic fracturing job are:

1. Make certain that enough land has been cleared for the necessary equipment.

2. Bring in sufficient tank storage for the job.

3. Bring in sufficient water (or other fluid) for the job.

4. Treat the water as required (add $\mathrm{KCl}$ or other chemicals as needed).

5. Bring in the sand or other proppant material.

6. Bring in the blending and mixing trucks.

7. Bring in the pumping trucks and crews required.

8. Set up for the fracturing job.

9. Run the job.

10. Log the we11.

11. Wait about 12 hours after completing the job (for the gel to break down).

12. Flare the well to produce back the fracturing fluid, igniting the flare as soon as the water content is low enough to allow ignition.

13. Remove the crews and equipment.

The location and types of equipment used are shown schematically in Figure 3.1. Figure 3.2 shows conceptually what is thought to occur in a multistage massive hydraulic fracturing operation in lenticular sandstones.

Mitchell Energy and Development Corporation recently set a record on a successful hydraulic fracture job in East Texas. The MHF, which used Haliburton Services as the contractor, used 2.8 million pounds of sand and 860,000 gallons of fluid. The fracture was designed to be a maximum of 210 feet high vertically and 2700 feet long horizontally on each side of the wellbore. This project was done with the financial support of DOE. 


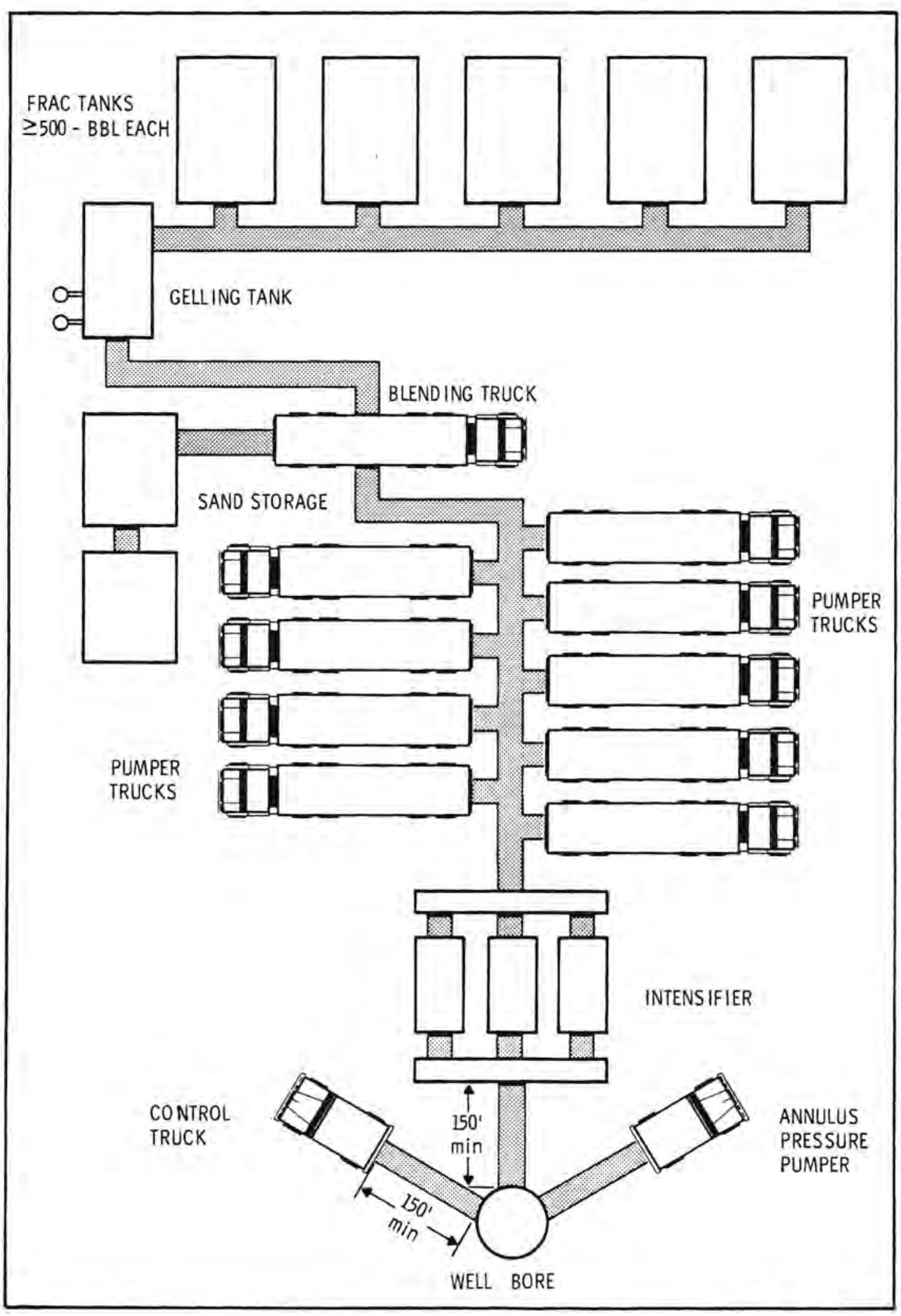

FIGURE 3.1. Equipment Types and Location During an MHF Job 


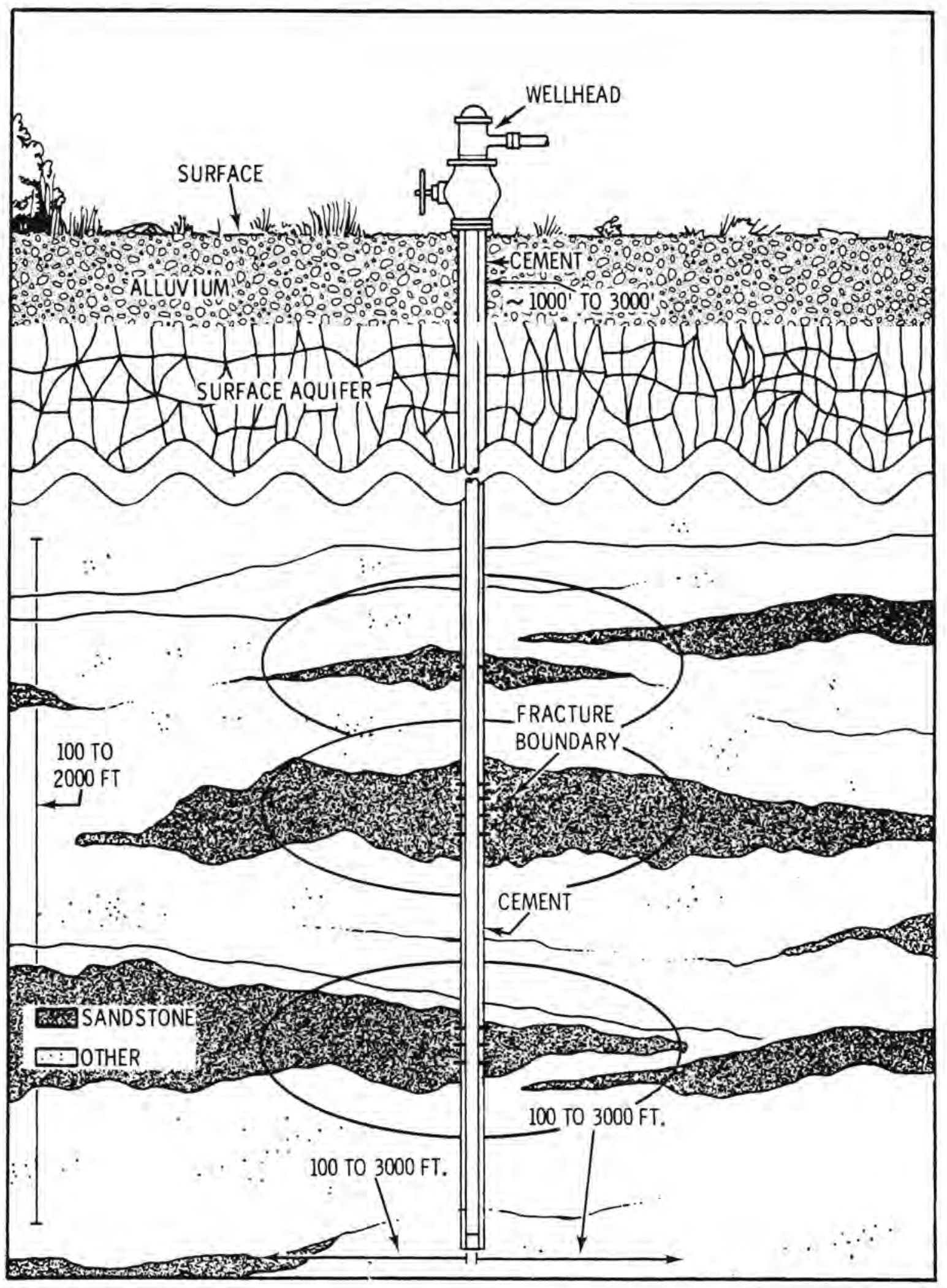

FIGURE 3.2. Muttistage Massive Hydraulic Fracturing Job 


\subsubsection{Foam Fracturing}

In the foam fracturing (FF) procedure, which is conceptually similar to an MHF, compressed gas and water containing a number of additives, one of which must be a surfactant ( $a$ foaming agent), are pumped down the tubing string under sufficiently high-pressure to cause formation breakdown and fracturing. Foam fracturing has the advantage over the conventional MHF jobs in that very little water is used and, thus, the well cleans up much faster. Foam fracturing jobs range in size from very small ones to jobs that are massive. However, since one of the components is a gas, there are depth limitations due to the fact that pressure increases with depth and foaming decreases with pressure. As a consequence, FF is normally restricted to formations that are not more than 5,000 to 6,000 feet deep.

\subsection{CHEMICAL EXPLOSIVE FRACTURING}

Chemical explosive fracturing $(C E F)^{(a)}$ is a method in which an explosive fluid is injected under sufficient pressure to cause hydraulic fracturing to occur. An important ingredient which is missing is proppant agent. After the explosive fluid has been injected into the formation, it is detonated. This detonation causes further fractures to grow and at the same time generates, in situ, a proppant material. The end result is something, in theory, that is quite close to an MHF.

The only completed project in Tight Western Sands that used CEF is a three-well test in the Fort-Worth Basin of Texas. This CEF project used Talley-Frac Corporations' process and was supported financially by ERDA (now $D O E$ ). Fifteen thousand pounds of explosive slurry was injected through a two-inch tube in all three of the wells. These explosives were detonated by pumping a detonator plug on top of the slurry. The slurry itself causes some hydraulic fracturing to occur within the reservoir.

(a) CEF should not be confused with an older method of detonating an explosive charge contained within the wellbore. The procedure was a common method of stimulation used in the late 19th century. In CEF, the explosive slurry is used to first hydraulically fracture the formation before it is detonated. 
The actual reservoir selected for these tests is relatively shallow $(4000 \mathrm{ft}$ ), naturally fractured, and of low permeability. Production from wells within this reservoir varies from good to submarginal. Hydraulic fracturing has been employed to improve productivity.

Results of this demonstration proved to be disappointing. (One well was lost completely when the casing was separated by the explosion.) Comparison of the preshot and postshot performance of the other two wells showed no production increase in one well and a minor increase in another.

\subsection{NUUCLEAR STIMULATION}

Nuclear stimulation is the process of detonating a thermonuclear device deep underground. Three nuclear stimulations have been performed to date. These are:

- Project Gasbuggy detonated on December 10, 1967.

- Project Rulison detonated on September 10, 1969.

- Project Rio Blanco detonated on May 17, 1973.

These three experiments (Leutkehans and Toman 1976, p. 28) indicate that nuclear stimulation of gas production from unconventional sources is technically feasible. The locations of these three projects are shown in Figure 3.3.

\subsubsection{Project Gasbuggy}

Project Gasbuggy utilized a 30-kiloton thermonuclear explosive detonated at a depth of $4240 \mathrm{ft}$ in the Lewis Shale Formation of the San Juan Basin. The mechanical effects were determined through data gained by drilling pre- and postdetonation wells and by conducting production tests.

Various factors about the stimulation were determined by reentry dri11ing. The cavity formed by the explosion was calculated to be about $85 \mathrm{ft}$ in radius and about $415 \mathrm{ft}$ in height. The stimulation was successful. The initial gas produced was contaminated by the radioactive nuclides tritium and krypton and also by a large quantity of $\mathrm{CO}_{2}$ gas. After producing two to three cavity volumes of gas, the produced gas has a composition close to that of the native reservoir gas. 


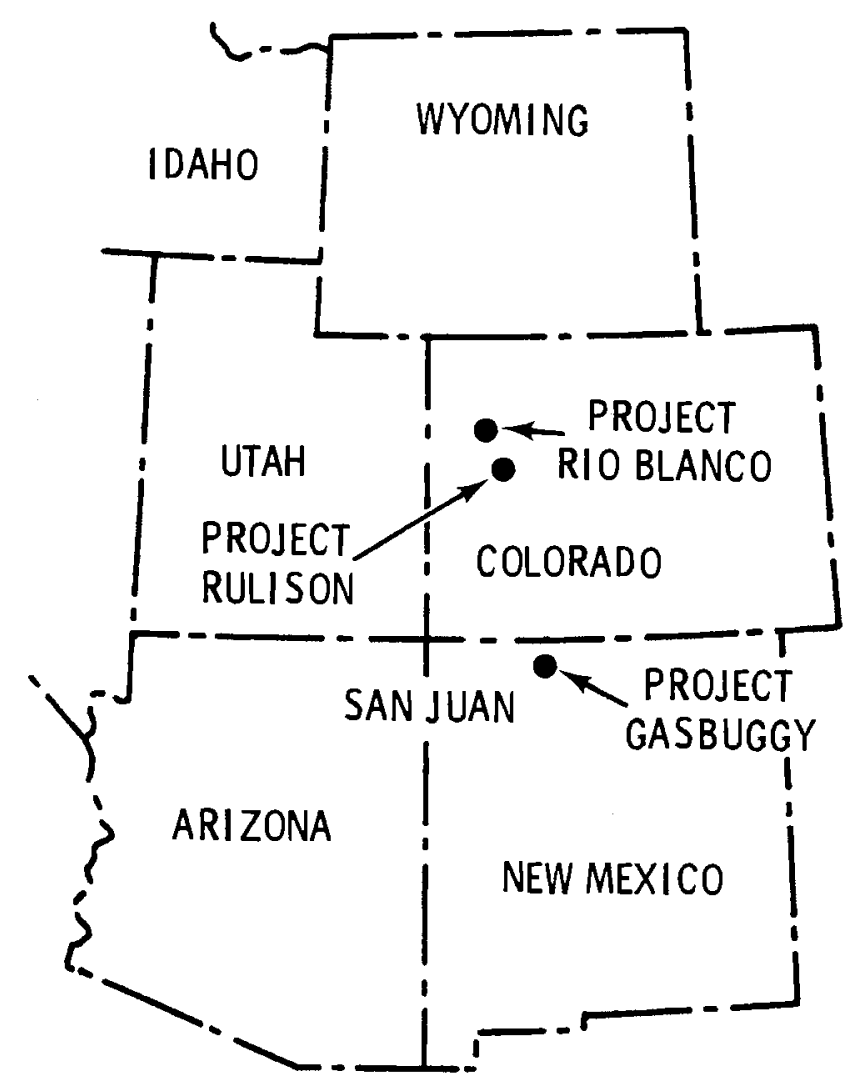

FIGURE 3.3. Locations of the Three Nuclear Stimulation Tests

\subsubsection{Project Rulison}

Project Rulison utilized a 45-kiloton thermonuclear explosive detonated at a depth of $8426 \mathrm{ft}$ in the Mesaverde Formation. A small diameter explosive was emplaced in a 10-3/4-inch casing thereby providing a sizeable economic advantage over Gasbuggy which required a 20-inch casing. In addition, the resulting residual tritium was approximately one-fourth that of Gasbuggy.

Reentry drilling and production testing were done in order to examine how the cavity and gas had changed as a result of the stimulation treatment. The cavity formed in the explosion was determined to be approximately $75 \mathrm{ft}$ in diameter and approximately $350 \mathrm{ft}$ in height. The initial gas was contaminated by the radioactive nuclides tritium and krypton 85 . The initial gas also contained very large quantities of $\mathrm{CO}_{2}$. After producing 455 MMCF (million cubic feet) of gas, the radioactivity of the produced gas was down to background levels. 
Postdetonation gas quality measurements agreed with predictions made based upon project Gasbuggy. One interesting sidelight of this test was the slight damage to several thousand buildings that were within a 20-mile radius.

\subsubsection{Project Rio Blanco}

Project Rio Blanco involved the detonation of three 30-kiloton thermonuclear explosives placed in a single wellbore at depths of 5840,6230 , and $6690 \mathrm{ft}$ in an attempt to stimulate a 1300-ft interval in the Fort Union and Mesaverde Formations. The explosives were specifically designed for gas stimulation.

The explosives were smal1 enough to be used in a 7-inch casing. This was the first stimulation which required an environmental impact statement.

The cavities formed in each of the three explosions were of the same general size as those formed in the two previous tests. However, the three cavities did not coalesce. A11 three thermonuclear devices exploded successfully and had approximately equal yields.

\subsubsection{Conclusion}

Colorado Interstate Gas Company studied the marketing of gas from Project Rulison and found that the regulatory problems associated with the utilization of this gas were substantial. Time and economic considerations will preclude the selling of this gas.

Although these experiments have demonstrated that nuclear explosives can be used safely as a stimulation method, social and political factors currently preclude their use. 


\subsection{BARRIERS TO COMMERCIAL PRODUCTION}

As discussed in Section 3, several technically feasible methods exist for recovering natural gas from Tight Western Sands. However, before these resources can become commercially viable, several barriers or issues must be resolved. The primary barriers affecting Tight Western Sands production are economics, water resources, and lack of risk capital to finance drill rigs and crews.

\subsection{ECONOMICS}

Because of the large distances from well fields to commercial pipelines and the low production rates of the gas wells, the economics of Tight Western Sand basins are marginal. As demand and price for domestic natural gas increases, the profits from these gas fields will increase thereby stimulating production.

\subsection{WATER RESOURCES}

Competition for available water resources is a serious issue in the arid west, especially during periods of low rainfall. Since the majority of the Tight Western Sands gas resource exists in this area, competition for available water resources is an important factor in gas field development. The fullscale development of this resource in the West, in combination with development of other energy resources (oil shale), could result in a chronic water availability problem during periods of low precipitation.

The alternatives for using water in Tight Western Sand production are as follows:

- Surface water (via pipeline or truck)

- Ground water (onsite or truck)

- Runoff collection and use

Conservation techniques that could be applied to these alternatives include recycling (already practiced by well drillers who are the biggest water consumers), using natural gas rather than water drilling, and scheduling activity to coincide with elevated stream flows. 
of the alternatives and conservation techniques mentioned, currently the most economically viable alternatives are either short distance pipeline transport of surface water to the site or use of ground water obtained through onsite wells. Both preferred alternatives should incorporate as much recycling as possible, especially during drilling and fracturing activities to provide for prudent use of the available resource.

The surface-water resource availability question has been studied fairly extensively (Booz, Allen and Hamilton Inc. 1978). Conclusions that can be drawn from such studies are as follows:

- Not considering total water uses for dust control, mud drilling operations consume by far the greatest quantity of water.

- Enhanced gas recovery activities in the western U.S. will consume between 800 and 1600 acre-feet of water/year assuming an average of 600 active wells.

- Rivers potentially incapable of sustaining this development during extreme low flows include the Powder (in the Northern Great Plains UGR basin), the Sabine (in the Cotton Valley UGR basin) the Rio Grande (near the Sonora UGR basin), and the Arkansas (in the Denver Basin) Rivers, which all had little or no flow at certain locations during the extreme low stream flow conditions occurring in 1966 - 1970 shown in Table 4.1 (Booz, Allen and Hamilton Inc. 1978). Other rivers have approached near zero flow levels and could be restricted to high flow use only (the Yampa in the Green River UGR basin, the Milk in the Northern Great Plains UGR basin, and the Pecos in the Sonora basin).

The most important western river basins to the commercialization of UGR are highlighted in Table 4.2. Surface water requirements for the Missouri river basin (servicing the Denver, Williston/Northern Great Plains UGR basins), the Western Gulf river basin (servicing the Sonora and Cotton Valley UGR basins) and the Colorado river basin (servicing the Unita, Piceance, Green River, Wind river, and San Juan UGR basins) are 1175, 1485, and 703 acre-feet per year, respectively. 
TABLE 4.1. Average and Extreme Low Stream Flows for Potentially Usable Streams by UGR Basin (Booz, Allen and Hamilton, Inc. 1978)

\section{UGR Target - River/Location}

- Unita

Green River/Green River, UT

Duchesne/Randlett, UT

- Piceance

Gunnison/Grand Junction, CO

Colorado/CO-UT Border

Colorado/Cameo, CO

White/Watson, UT

- Green River

Green/Warren Br, WY

Green/Linwood, UT

Yampa/Maybe11, UT

- Williston

Missouri/Williston, ND

Missouri/Bismark, ND

Missouri/Wolfpoint, MT

Missouri/Mobridge, SD

Yellowstone/Sidney, MT

- Northern Great Plains

Mi $1 \mathrm{k} /$ Nashua, MT

Powder/Locate, MT

Missouri/Virgelli, MT

- Biq Horn

Yellowstone/Corwin Springs, MT

Missouri/Tostan, MT

Mighord/St. Xavier, MT

- Wind River

Wind River/Riverton, WY

- Denver

North Platte/WY-NB line

Arkansas/Syracuse, KS

- San Juan

San Juan/New Mexico

- Sonora

Pecos/Girven, TX

Rio Grande/Johnson River, TX

- Cotton Valley

Sabine/Emory, TX

Red/Arthur City, TX

Red/Shreveport, $L A$

- Ouachita

Ouachita/Malborn, AK

Little/Horatio, OK $\frac{\text { Acre Ft/Yr }}{\text { Average }}$

Extreme Low Flow Prior to 1960

$4,805,000$

$4,210,000$

482,200

$3,211,000$

382,100

255

463,300

$1,937,000$

$1,500,900$

$3,871,800$

$4,408,000$

$2,269,400$

526,300

454,020

886,500

$2,861,000$

$1,956,000$

364,700

370,200

$1,434,000$

$1,149,000$

364,860

- -

$1,031,560$

$14,900,000$

$15,380,000$

$6,640,000$

$16,080,000$

$8,400,000$

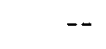

$19,092,000$

$8,694,000$

--

$--$

$$
\begin{array}{r}
543,000 \\
453,200 \\
5,625,000
\end{array}
$$

10
$2,187,000$

$3,655,000$

$2,588,000$

$2,457,600$

$4,082,400$

$2,639,400$

744,300

442,200

297,600

523,400

405,240

285,000

$1,756,000$

117,300

$1,022,372$

367,000

$6,501,000$

$18,430,000$

451,600
$5,348,000$
$16,938,000$

94,230
$3,439,000$

$1,643,200$

$1,055,000$

$2,620,000$

$1,941,000$

$2,744,000$

$1,133,000$

100

228

$1,709,000$

$2,853,000$ 
TABLE 4.2. Total Water Consumption by UGR Basin for Drilling and Fracturing Activities (BOoz, Allen and Hamilton, Inc. 1978)

\begin{tabular}{|c|c|c|c|c|c|c|}
\hline $\begin{array}{l}\text { Western Sands } \\
\text { Bas in }\end{array}$ & $\begin{array}{c}\text { \# Wells } \\
\text { (Peak Year) }\end{array}$ & $\begin{array}{c}\text { Average } \\
\text { Wel1 } \\
\text { Depth } \\
(1,000 \mathrm{Ft}) \\
\end{array}$ & $\frac{\text { Dril }}{\text { Ga1/Ft }}$ & 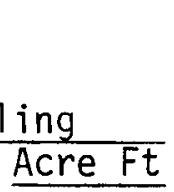 & $\begin{array}{c}\text { Frac } \\
(100,000 \\
\text { Gal/We11) } \\
\text { Acre Ft } \\
\end{array}$ & Total \\
\hline Unita & 60 & 8 & 59 & 87 & 18 & 105 \\
\hline Piceance & 10 & 8 & 59 & 15 & 3 & 18 \\
\hline Green River & 60 & 8 & 59 & 87 & 18 & 105 \\
\hline $\begin{array}{l}\text { Williston/North } \\
\text { Great Plains }\end{array}$ & 1210 & 2.5 & 49 & 456 & 370 & 826 \\
\hline Big Horn & 40 & 8 & 59 & 58 & 12 & 70 \\
\hline Wind River & 20 & 8 & 59 & 29 & 6 & 35 \\
\hline Denver & 230 & 8 & 49 & 278 & 71 & 349 \\
\hline San Juan & 210 & 8 & 59 & 305 & 65 & 370 \\
\hline Sonora & 280 & 8 & 78 & 534 & 86 & 620 \\
\hline Cotton Valley & 390 & 8 & 78 & 745 & 120 & 865 \\
\hline Cuachita & 10 & 8 & 78.5 & 19 & 3 & 22 \\
\hline
\end{tabular}

Assumptions: (1) 500,000 gal frac fluid/well of which $80 \%$ is recoverable.

(2) Cable tool or rotary drilling (using water rather than air drilling).

(3) $80 \%$ recovery and reuse of frac fluids for a net of 100,000 gal consumptive use per well.

(4) Water not included in estimate: domestic potable water and water used for dust control.

The use of surface water is restricted by the distance between the resource and the well. Aboveground, temporary pipelines are the preferred method for distances less than $5 \mathrm{kilometers} \mathrm{subject} \mathrm{to} \mathrm{economic} \mathrm{constraints} \mathrm{such} \mathrm{as} \mathrm{the}$ number and size of pumps needed, the head required, the number of excavations under roadways, the local terrain, etc. The current practice of hauling water considerable distances for pilot tests may continue for fracturing or other relatively low water consumptive jobs. The number of available tankers and cost of fuel will probably limit this alternative to small jobs. 
The use of ground water in the west may be extremely limited due to the high salinity content of many western aquifers. High salt content is unacceptable for use in many Unconventional Gas Recovery activities due to interaction with clays followed by swelling and subsequent well production slowdown. The aquifers of the Denver, Green River, and Piceance basins al1 fall into this category. It has been estimated that $70 \%$ of the upper Colorado ground water contains greater than $1,000 \mathrm{mg} / \mathrm{l}$ dissolved solids (Booz, Allen and Hamilton Inc. 1978). In addition, new federal regulations such as the Safe Drinking Water Act of 1976 may impact ground-water withdrawal and injection activities. Problems of general lack of water and the possibility of resource depletion are present in the Denver, Unita and Piceance Basins (Booz, Allen and Hamilton Inc. 1978). However, field wide development is currently underway in the Wamsutter area of the Greater Green River Basin using tankers to haul the water.

In conclusion, water availability will probably be the most significant constraint to Tight Western Sand gas commercialization.

\subsection{RISK CAPITAL AVAILABILITY}

One of the major obstacles to major expansion efforts in the Tight Western Sand Basins is a lack of uncommitted drill rigs and crews in the local areas. This is not a result of an overall shortage of rigs or crews but is rather the result of lack of committed risk capital.

In spite of the fact that the Hughes Rig Count stands at an all time high, approximately $20 \%$ of a 11 drill rigs are sitting idle. The number of rigs drilling wildcat wells has been on the decline in recent years.

Risk capital is allocated on the basis of the potential profitability of areas available for exploration. Currently, the most active area for exploration is the overthrust belt of Wyoming, Idaho, Utah, and Montana. This area is producing a large number of new gas and oil fields. The capital for exploration in the Tight Western Sands Basins is based on what is left over from exploration and development in these areas that promise a better return on investment of risk capital. 



\subsection{ASSESSMENT OF ENVIRONMENTAL HEALTH AND SAFETY IMPACTS}

The purpose of this chapter is to present an assessment of the environmental, health and safety impacts for normal operations during development of a tight western sands gas field. The chapter identifies research needs required to generate data not currently available, but needed to improve the assessment of impacts. The impacts are examined for each of the field development stages identified in Appendix A.

\subsection{ENVIRONMENTAL ASSESSMENT}

This section examines the potential impact of gas field development on air quality, water quality and the ecological environment. Table 5.1 shows the potential environmental impacts from gas field development. In most cases, as the discussion below indicates, impacts are minor or temporary.

\subsubsection{Exploration}

There are three activities associated with exploration for gas in tight western sand that could result in environmental impacts: 1) seismic exploration, 2) construction of temporary roads, and 3) wild cat drilling. Wild cat drilling is the same as regular development drilling from an environmental viewpoint; therefore, it will be discussed in the development section.

Seismic exploration work for the tight western sand basins is completed. When seismic exploration was being done, its main impacts resulted from a small amount of particulates released by the explosion and a short-term loud noise which could temporarily startle and frighten animals in the vicinity (Connteneau 1978). Because of the remote location of the tight western sand basins, some off-road travel was needed to transport exploration equipment. off-road vehicular traffic damages every kind of ecosystem by damaging soil, crushing vegetation, and killing or disturbing wildlife. Desert soils are particularly vulnerable to off-road vehicle traffic because once the soil is broken down and vegetative cover stripped away, such soils become susceptible to wind, water and mechanical erosion (Council of Environmental Quality 1979). Based on the number of exploratory wells drilled, the amount of land impacted by off-road vehicle traffic compared to the total area of the basin is small; therefore, the impact is minimal. 


\section{TABLE 5.1. Potential Environmental Impacts from Gas Field Development}

\begin{tabular}{|c|c|c|c|c|c|c|c|c|c|}
\hline & $\begin{array}{c}\text { Air } \\
\text { Pollution }\end{array}$ & $\begin{array}{l}\text { Surface } \\
\text { Water }\end{array}$ & $\begin{array}{c}\text { Ground } \\
\text { Water }\end{array}$ & $\begin{array}{l}\text { Land } \\
\text { Us e }\end{array}$ & _- Flora & Fauna & $\begin{array}{l}\text { Availability } \\
\text { water }\end{array}$ & Noise & Geological \\
\hline Exploration & $\begin{array}{l}\text { Duration } \\
\text { very short, other: } \\
\text { none }\end{array}$ & - & -- & -- & Very short & $\begin{array}{l}\text { Very short } \\
\text { (noise) }\end{array}$ & -. & $\begin{array}{l}\text { Loud during } \\
\text { seismic blast }\end{array}$ & $\therefore$ \\
\hline Drill Pad Siting & $\begin{array}{l}\text { Duration short, } \\
\text { noderate overail }\end{array}$ & $\begin{array}{l}\text { Very long } \\
\text { areas large }\end{array}$ & -- & 4 to 5 acres/pad & Very long & slight & -- & $80 \mathrm{db}$ & -- \\
\hline Drilling & $\begin{array}{l}\text { Duration moderate } \\
\text { slight overall }\end{array}$ & moderate & $\begin{array}{l}\text { moderate } \\
0 \text { to very } \\
\text { slight }\end{array}$ & - & - & - & $\begin{array}{l}6000 \mathrm{BB}: \mathrm{H}_{2} \mathrm{O} \\
\text { very slight }\end{array}$ & $\begin{array}{l}\text { Land and } \\
\text { long duration }\end{array}$ & -- \\
\hline Stimulation & $\begin{array}{l}\text { Duration very } \\
\text { short, high }\end{array}$ & Very slight & $\begin{array}{l}0 \text { to very } \\
\text { slight }\end{array}$ & - & -- & Very slight & $\begin{array}{l}\text { water must be } \\
\text { trucked in }\end{array}$ & $\mathrm{L}_{p}$ to $100 \mathrm{db}$ & $\begin{array}{l}\text { Very } \\
\text { slightit }\end{array}$ \\
\hline Pipelines & $\begin{array}{l}\text { Duration moderate } \\
\text { slight }\end{array}$ & $\begin{array}{l}\text { Moderate area } \\
\text { small }\end{array}$ & -- & $\begin{array}{l}\text { Large areal } \\
\text { extension }\end{array}$ & Short & Very slight & - & $\begin{array}{l}\text { Slight noise } \\
\text { during construction }\end{array}$ & -. \\
\hline Rodds & $\begin{array}{l}\text { Duration moderate, } \\
\text { slight to moderate }\end{array}$ & $\begin{array}{l}\text { Very long, } \\
\text { very slight to } \\
\text { slight, area } \\
\text { large to very } \\
\text { large }\end{array}$ & -- & $\begin{array}{l}\text { Large areal } \\
\text { extension }\end{array}$ & Very short & Very short & -- & $\begin{array}{l}\text { Slight during } \\
\text { construction }\end{array}$ & - \\
\hline Production & Slight & - & -- & Same as pad & $\begin{array}{l}\text { Slight due } \\
\text { to noise, } \\
\text { traffic }\end{array}$ & $\begin{array}{l}\text { slight due } \\
\text { to noise. } \\
\text { traffic }\end{array}$ & - & $76 \mathrm{db}$ & -- \\
\hline Restoration & $\begin{array}{l}\text { Duration short. } \\
\text { slight }\end{array}$ & - & -- & $\begin{array}{l}\text { Return to } \\
\text { original use }\end{array}$ & - - & - & $\begin{array}{l}\text { Very slight } \\
\text { to } 0\end{array}$ & $\begin{array}{l}\text { Slight during } \\
\text { restoration }\end{array}$ & - \\
\hline
\end{tabular}


Construction of temporary roads will result in air pollution from diesel truck emissions and dust, destruction of flora, disturbance of fauna and may result in degradation of surface water quality due to erosion. Most of these impacts are covered under construction of permanent roads in the field development section. The impact of temporary roads will be less because the miles of road will be less. Temporary roads differ from permanent roads only in the potential for erosion. Erosion from temporary roads is much higher because temporary roads are not required to have culverts. However, because of the arid conditions in the basins, erosion would be intermittant since many small streams are intermittant or nonexistant. This intermittant erosion phenomenon is common in the western arid area, and temporary road construction should add little to the erosion problem.

\subsubsection{Field Development}

The activities associated with development of a tight western sands gas field that could potentially result in environmental impacts are:

\section{Construction of roads}

2. Construction of pipelines and distribution facilities

3. Drilling of production wells

4. Stimulation of production well

5. Construction of treatment facilities

\section{1 .2 .1 Roads}

The construction of permanent roads would result in the largest areal impact. For a 100-square mile well field the minimum number of miles of road to be constructed would be 100 miles. Based on the 100 miles of road, the minimum cleared area would range from 300 acres $(0.5 \%$ of total well field area) for a $30-\mathrm{ft}$ road bed to 240 acres $(0.4 \%)$ for a $20 \mathrm{ft}$ road bed. In many cases, because the roads are being built in an area of steppes and buttes, the actual road miles will probably be two or three times this minimum but still only represent a disturbance of $1-2 \%$ of the total well field area. Removal of flora and fauna will occur along all road beds. The amount of flora or fauna removed will have a minimal effect on the total ecosystem because of the small amount of land involved. 
Since there will be increased road traffic in the area, the probability for road kill will increase. The net road usage is low (a few trips per week), however, and the net probability for road kills will be slight.

During construction of the road, the principal pollutant will be air pollution, mostly diesel engine emissions and dust. The impact of diesel emission on air quality is anticipated to be minimal except in the immediate vicinity of the road equipment because of the good atmospheric dispersion characteristics and the lack of sensitive environments in the immediate vicinity. Dust will be a severe local problem at the construction site and during high wind conditions. These regions already have very high total suspended particulate (TSP) levels during high wind conditions (Williams 1978, Blusen 1979). However, the small amount of road constructed is anticipated to add very little to these TSP levels.

In addition to air pollutants, diesel engines create approximately $80 \mathrm{db}$ of noise. This level of noise will disturb neighboring fauna. It may cause them to flee from the immediate area and may also disturb breeding and brooding (Janssen 1978). Road construction activities will last only a few days at one site so permanent impacts due to air pollutants should not occur.

Erosion and runoff from the road bed may result in some surface water pollution. However, the region of the tight western sand basins are arid and permanent roads are required by law to be constructed with culverts. Therefore, the potential for erosion impacts are minimal.

\subsubsection{Pipeline}

In addition to construction of roads for transporting well field equipment, development of a gas field requires construction of pipelines between wells and to the nearest commercial transmission pipeline. Within a 100-square mile gas field, the pipeline will be approximately 100 miles long. This is equal to the minimum road distance since the presence of steppes and buttes do not significantly alter the pipeline length. Distance to the nearest commercial transmission pipeline is highly variable and may only be determined in a field-by-field case. If the pipelines are buried (though they need not be buried), a backhoe digs a trench about 10 inches wide that after burial of 
the pipe is recontoured and reseeded. Based on the 100 miles of pipeline, the total amount of land disturbed within the gas field would be approximately 10 acres $(0.02 \%)$. Disturbance to flora and fauna would, therefore, be minimal. Noise and atmospheric emissions from the construction equipment will result in minor impacts because of their short duration and low levels.

\subsubsection{Production Wells}

The major activity associated with development of the gas field is drilling of the wells. The major impact from the drilling is clearing of the drill pad, which may cover three to four acres. Included in this acreage is a mud pit for disposal of drilling muds and waste production water. The mud pit is about $1 / 4$ acre in area and the smaller flare pit occupies about 600 square feet. Based on a four acre pad, the total area occupied by drill pads for the entire developed field will be about 400 acres $(0.6 \%)$.

All vegetation on the well pad sites is totally destroyed. In addition, nest sites for small mammals and birds may be destroyed. Depending on the season of the year, young animals and brooding adults could also be killed. Most large and small animals will be driven from the site to outlying areas.

The construction equipment noise of about $80 \mathrm{db}$ will cause many animals to flee from the surrounding area and depending on the season of the year could interfere with breeding. This noise level is not expected to cause any permanent damage to the wildlife because the noise level is not excessive (Janssen 1978) and should last for a maximum of about one to three months at each drilling site.

Air pollution resulting from construction of the drill pad will result from diesel engines and wind blown dust. The diesel engines emit $\mathrm{CO}, \mathrm{SO}_{\mathrm{x}}$, NO $x$, hydrocarbons and particulates. Dust will be a problem during construction and for the life of the pad site. Dust should have an impact only in the immediate vicinity of the construction site and should remain well below air quality standards a short distance from the site. During high wind conditions, dust from the construction area would add to the already high TSP levels although the addition will be very small. 
During drilling, the major potential sources of pollution are the air emissions from the 1000 to $1500 \mathrm{hp}$ diesel engines and potential ground water pollution from the drilling mud pit.

The diesel engines will run continuously, 24 hours a day; for a month. Primary emission will be $\mathrm{CO}, \mathrm{SO}_{x}$, $\mathrm{NO}_{x}$, hydrocarbons and particulates. The standard emission quantities for diesel engines are given in Table 5.2. These values are very small and will be well below air quality standards in a few hundred feet. Normally only one or two drilling rigs will be operational, at any given time, in a field, that may cover 100 square miles. These emissions, averaged over the entire gas field, will be quite small and well within even primary air quality standards.

\section{TABLE 5.2. Emissions from One $1100 \mathrm{hp}$ Diesel Engine}

\begin{tabular}{|c|c|}
\hline Pollutant & $\begin{array}{l}\text { Quantity } \\
\text { (g/sec) }\end{array}$ \\
\hline $\mathrm{SO}_{\mathrm{x}}$ & 2.08 \\
\hline $\mathrm{HC}$ & 1.63 \\
\hline $\mathrm{NO}_{\mathrm{X}}$ & 2.84 \\
\hline $\mathrm{CO}$ & 2.50 \\
\hline Particulate & 0.80 \\
\hline Aldehydes & 0.13 \\
\hline
\end{tabular}

The noise generated by the continuous operation of the diesel engine will be $76 \mathrm{db}$ (40 CFR 204.52). However, the engine will be located near the center of the drill pad and the calculated decibel level at the edge of the pad about 400 feet from the engine will be reduced from $76 \mathrm{db}$ to $51 \mathrm{db}$. Fifty-one db is approximately the level of noise in an average home (Noise and You 1978, Battelle Today 1979) and is not, therefore, anticipated to adversely impact the fauna.

The mud pit will contain less than $400 \mathrm{~m}^{3}$ of fluid. Constituents of the drill mud water are normally non-toxic and have been deemed so by the EPA in conjunction with the Resource Conservation and Recovery Act of 1976 (RCRA) 
(PL 94-580). The only "toxic" element which could be present in mud or naturally contaminated waste water is barium. The concentration of the element is expected to be less than the $10-\mathrm{mg} / \mathrm{l}$ level set by EPA as the concentration which is potentially toxic to public health (National Interim Drinking Water Regulations 1976, Development of Environmental Monitoring Guildelines for EOR and EGR Processes 1978, Vol. II). Under normal conditions, drilling mud fluids will be isolated from potential public exposure pathways by high dike construction and the high evaporation index and groundwater levels will below the surface (Williams 1978), which will prevent exposure by cattle, surface water contamination and ground-water contamination, respectively.

The pits are fenced to prevent ground animals from drinking the fluids. Where migratory bird flyways may overlap the drilling areas, state and federal regulations require that the mud pits be covered to prevent exposure to the wasted fluids.

\subsubsection{Treatment and Distribution Facilities}

At each well site in the gas field, distribution and gas treatment facilities are constructed to collect the gas, remove liquid gas elements and pump the gas into the local pipeline. Construction of these facilities will be on the three to four acre pad cleared at the drill site and requires only hauling in and hooking up the machinery. Therefore, impacts on air quality, wildiife or waterway should be minimal.

\subsubsection{Stimulation}

To get reasonable flow rates from the well, the wells are stimulated using an advanced hydraulic fracturing method. The principal potential pollution sources are air pollution from diesel engines during the fracturing job and minor spills of the chemicals used in the fracturing fluid. Contamination of freshwater aquifers with fracturing fluids components is another potential source of environmental impact during we 11 stimulation. Current practices to prevent this appear to be effective. It is expected that ground-water contamination will only occur if cementing of the casing was not properly done. The potential for performing a stimulation in a well with inadequate casing is believed to be low because cement bond logs are run to insure a good bond. 
Fracturing should not result in seismic effects in the basins because:

- The volume used in a fracturing job are from one-tenth to one-thousandth of the amounts which have triggered seismic events.

- The basins are not planned to be drilled or fractured near any fault blocks.

- Past fracturing jobs have not resulted in seismic activity (Pakiser et al. 1969, Development of Environmental Monitoring Guildelines for EOR and EGR Processes 1978, Vol. 1).

During the fracturing job several large diesel engines will be used to pump the fluid under high pressure into the well. These large diesel engines will result in locally very high levels of air pollutants and noise. Based on standard emmission factors for diesel engines and ten diesel trucks, the air pollution levels expected during the operation are given in Table 5.3.

\section{TABLE 5.3. Emissions from a Typical Stimulation Job}

\begin{tabular}{llll} 
Pollutant & & $\begin{array}{c}\text { Release } \\
\text { Rate } \\
(\mathrm{g} / \mathrm{sec})\end{array}$ & $\begin{array}{c}\text { Total } \\
\text { Release }\end{array}$ \\
\cline { 1 - 1 } $\mathrm{SO}_{\mathrm{X}}$ & & $\begin{array}{l}21.23 \\
\mathrm{HC}\end{array}$ & 229 \\
$\mathrm{HC}$ & & 16.6 & 179 \\
$\mathrm{NO}_{\mathrm{X}}$ & & 28.93 & 312 \\
$\mathrm{CO}$ & & 25.46 & 275 \\
Particulate & 8.2 & 89 \\
Aldehyde & & 1.32 & 14
\end{tabular}

(a) Based on an average total job time of $3 \mathrm{hrs}$.

Calculating the dispersion of these releases, air quality standards will be exceeded for about a mile from the site, however, in less than a few miles dilution should result in pollution levels well below ambient air quality standards. 
Noise levels will also be high, on the order of $100 \mathrm{db}$ at the center of the pad (Noise and You 1978) or $58 \mathrm{db}$ at the edge of the pad. The level of noise at the perimeter of the pad is about the level of normal conversation and may cause dispersal of fauna.

Fracturing jobs usually last three to eight hours and, therefore, the impacts over the long term will probably not be measurable. The constituents of fracturing fluid are non-toxic, so provided spills are cleaned up, no impact from chemical spills will result.

\subsubsection{Production}

During production there is very little activity at the well site. The surface facilities are routinely maintained and the wells are logged and may be tested. Neither of these activities should result in measurable impact. During production any brine produced by the well will be separated from the gas and disposed of in the mud pit. The amount of brine produced is small, especially in comparison to the evaporation index, and should not result in any environmental impact or ground-water contamination. A small number of road kills might result during the transportation of maintenance crews.

\subsubsection{Abandonment}

Abandonment of a gas field under current permitting regulations requires plugging and marking the wells, removal of surface facilities and recontouring and reseeding of well pads and roads (See Appendix A). These abandonment activities will require use of equipment with diesel motors similar to the construction activities and should likewise result in no measurable air quality impact. Seeding with native flora should reduce erosion possibility and start succession to the original flora mix.

\subsection{HEALTH AND SAFETY ASSESSMENT}

This section will examine the human health and safety impacts that could potentially result from development of a gas field. The primary areas of interest are the effects of changes in air quality, accidents and noise. In addition, handling of radioactive tracers will also be examined. 
During many parts of the well field exploration, development, production and abandonment, diesel trucks and engines will be operating, releasing into the air $\mathrm{CO}, \mathrm{SO}_{x}, \mathrm{NO}_{x}$, hydrocarbons and particulates. The concentrations of these constituents at any time depends on the number of engines operating and atmospheric conditions. The highest concentration of these air pollutants is most likely to occur during a fracturing job. At this time, diesel engines will be operating at full capacity. The amounts of each of the air pollutants produced and given in Table 5.3 .

CO produced from these operations is expected to reach 15-50 ppm near the source under calm wind conditions. These levels will not exceed the threshold limit value for workroom environments but could cause somatic worker effects. Myers et al. (1970) estimates that $50 \mathrm{ppm}$ would be the level at which one might expect some reduced mental acuity and headaches over a 10-hour period (see Figure 5.1). Since noise is believed to lower susceptability levels, one would also suspect that $c 0$ combined with elevated noise levels may have a synergistic effect thereby intensifying the potential acuity problem.

Other effects of slightly elevated carbon monoxide concentrations include cardiac function effects ( $330 \mathrm{ppm} \mathrm{CO}$ ) and work performance impairment ( $120 \mathrm{ppm}$ ). Poisoning however, is rarely reported at levels below $60 \mathrm{ppm}$ because it is asymptomatic (Sax 1957).

Based on the calculated concentrations of the diesel exhaust constituents, these constituents such as sulfur dioxide $\left(\mathrm{SO}_{2}\right)$, photo chemical oxidants, nitrogen dioxide, and particulates are not expected to exceed the "alert levels" as specified in the Clean Air Act (PL 91-604). More research is needed to determine the health effects of diesel exhaust since diesel particulates are bonded to organic compounds which have been shown to be at least mutagenic and may be carcinogenic (Environmental Reporter 1979).

Particulates due to traffic, construction of roads and dri11 pads, and wind scouring of exposed surfaces will present, visually, an air pollution problem. Each new mile of road and acre of cleared drill pad will add to the particulate grain loading of the local area. Such effects, however, will be extremely localized, especially for dusts greater than 5 micrometer $(\mu)$ in 


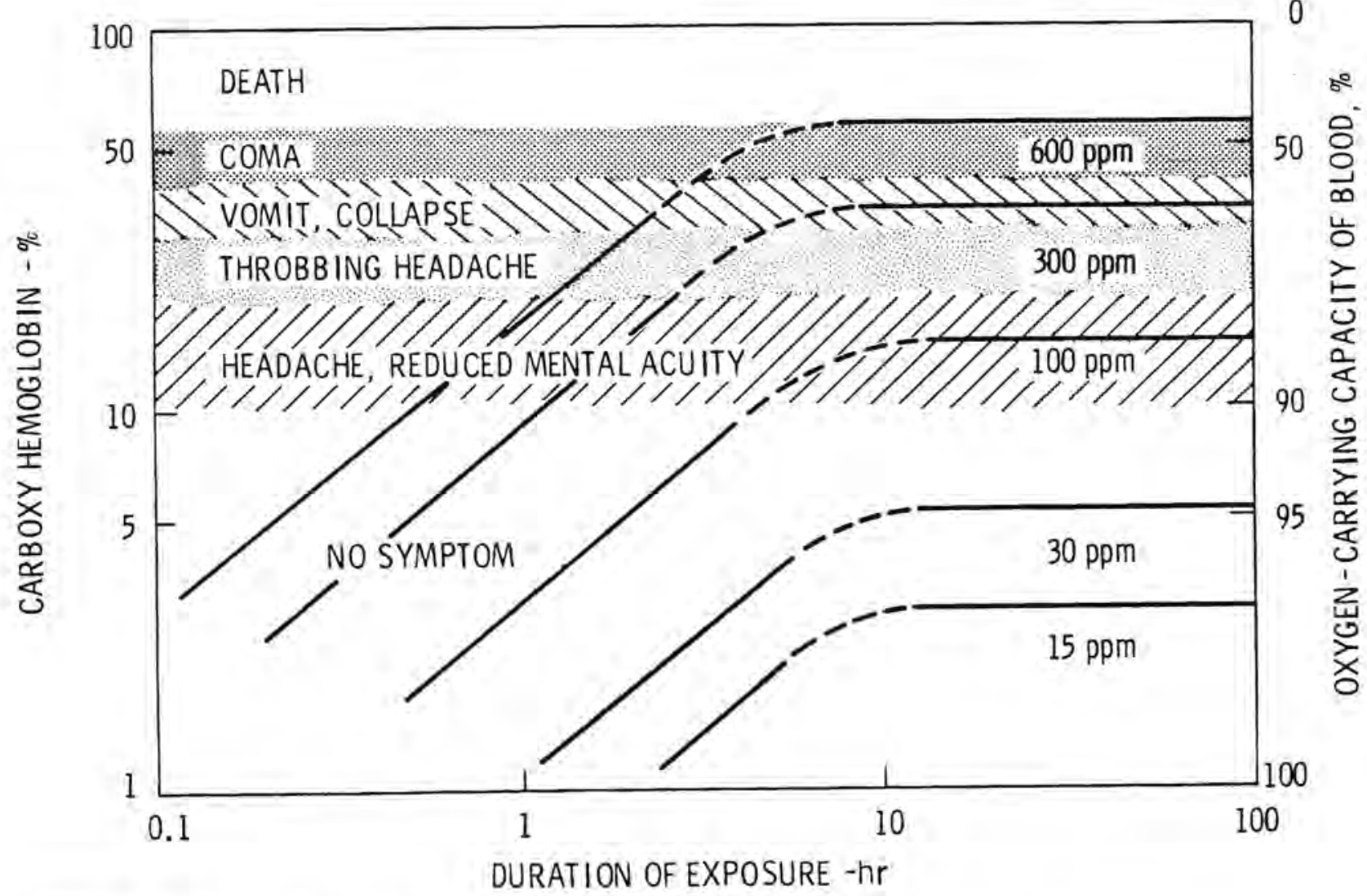
FIGURE 5.1. Reiationship Between CO Exposure (Hours and Concentration) Versus
Health Effects

diameter. Based on this size particle, only unstable atmospheric/high wind conditions will permit the carrying of dust particles more than one kilometer. The only potential health hazard would be the enhanced spreading of airborne fungi attached to dust particles which are subsequently inhaled by susceptible individuals. Such cases are rare, the most notable being San Joaquin Valley Fever (Coccidiomycocis) in southern California (Berenson, 1975).

Accidents that can result in injury to workers happen in any industry. Gas well drilling is a relatively accident free environment (Accident Facts 1977). Very few major accidents are expected al though numerous minor injury accidents will occur because of the proximity of heavy equipment.

Noise levels will also be highest during the fracturing job. It has been estimated that noise levels during running of the diesel trucks may be $100 \mathrm{db}$ or higher for about three to eight hours. This is considerably higher than the $90 \mathrm{db}$ level at which OSHA recommends that an effective hearing conservation 
program be implemented (29 CFR 1910.95). If adequate hearing protection is not provided, the exposures of a worker on a continuing basis could result in a hearing loss to workers.

Another potential safety hazard to workers could result from exposure to fracture sand which has had Ir-192 added to it as a tracer. Each can of tracer contains $5 \mathrm{mCi}$ of activity and 5 cans are used per job. In a single fracture job, a worker is calculated to receive a dose of 12 to $20 \mathrm{mrem}$ from direct exposure over a 2 to 3 hour working time. If that same worker handled the radioactive tracer for 3 fracture jobs per week for 50 weeks based on the dose for one job he may receive a dose of as much as 2 to 3 rem per year. Calculations were also performed to estimate the potential dose to a worker from inhalation of Ir-192. The highest organ dose rate calculated was $3 \times 10^{-2}$ rem per year based on a relatively insoluble $\mathrm{Ir}-192$ and 150 jobs/year. Therefore, radiological inhalation is not anticipated to represent a significant safety hazard to workers. However based on the potential dose from direct exposure, the worker should be monitored and taught safety procedures for dealing with radioactive materials. 


\subsection{CONCLUSIONS AND RECOMMENDATIONS}

No significant environmental barriers to the development of the Tight Western Sand Basins gas resource have been identified. The most important environmental impacts identified were from health and safety impacts occurring during the fracturing operation. These impacts result from the large amounts of diesel emissions that are released from the diesel engines and from high levels of noise. Environmental impacts can also result from road construction, well pad clearing and well drilling, however, it appears that most of these effects would be localized and/or temporary. There are limitations in current abilities to predict and assess these effects. It is therefore recommended that further work be done to improve knowledge in the areas of health and safety impacts of high levels of diesel emissions and of health and safety impacts of high levels of noise.

Pollution of ground water during well stimulation has been identified as another area with potential to produce significant environmental effects. Procedures in place to prevent ground-water contamination appear to be effective. There are no procedures currently in use to monitor for ground-water pollution directly. Procedures currently available to perform ground-water monitoring, such as drilling test wells are economically prohibitive and their use could result in a net increase in environmental effects. Because of the uncertainties surrounding this issue, it is recommended that a research program be developed to determine the effectiveness of current techniques used to prevent ground-water contamination. This program could form the basis for developing new controls, if they are needed.

The principal barriers to utilization of this resource are economic and technical. Economic and technical barriers are expected to be overcome by current governmental pricing policies that give favorable treatment to development of unconventional gas resources and by improving the treatment of hydraulic fracturing and the methods for obtaining reservoir data (both geophysical and geological as well as engineering). Although current procedures have proved effective in some applications, improvements are needed in both of these technical areas. 


\section{REFERENCES}

Appledoon, C. R., and R. L. Mann. 1977. "Massive Hydraulic Fracturing Gas Stimulation Project." In Proceedings of Enhanced 0i1, Gas Recovery and Improved Drilling Methods, P. E-2/1, Energy Research and Development Administration, Washington, DC.

Battelle Today. 1979. No. 12, Battelle Memorial Institute, Columbus, OH.

Berenson, A. S. 1975. Control of Communicable Disease in Man. 12th Edition, fmerican Public Health Association, Washington, D.C.

Booz, Allen and Hamilton Inc. 1978. Water Resources Availability for Enhanced Gas Recovery (EGR) Technology Development. Prepared for the Office of Resource Application, Department of Energy, Washington, D.C.

Clusen, R. 1979. Regional Issue Identification and Assessment First Annual Report. Department of Energy, Washington, DC.

Cotteneau, P. H. 1978. Effect of Sonic Boom from Aircraft on Wildlife and Animal Husbandry in Effects of Noise on Wildlife. J. L. Fletcher and R. G. Busnel, ed., Academic Press Inc., New York, NY.

Council of Environmental Quality. 1979. Off-Road Vehicles on Public Lands. CEQ-722, Jackson Place N.W., Washington, DC.

Environmental Reporter. 1979. 10(7): 230, Bureau of National Affairs, Washington, DC.

Frick, T. C., ed. 1972. Petroleum Production Handbook. Vol. II, Society of Petroleum Engineers of A $\overline{\mathrm{IME}}$, Dallas, TX.

Ham, J., and L. Dewey. 1978. Commercialization Plan for Unconventional Natural Gas Resources. Department of Energy, Washington, DC.

Howard, G. C., and C. R. Fast. 1970. Hydraulic Fracturing. Henry L. Doherty Memorial Fund of AIME, Society of Petroleum Engineers of AIME, New York, NY.

Janssen, R. 1978. Noise and Animals: Perspectives of Government and Public Policy in Effects of Noise on Wildlife. J. L. Fletcher and R. G. Bumel, ed., Academic Press Inc., New York, NY.

Knutson, C. F., and C. R. Boardman. 1978. Continuity and Permeability Development in the Tight Gas Sands of the Eastern Uinta Basin, Utah. Technical Report No. NVO/0011-1, C. K. Geo-Energy Corporation, Las Vegas, NV.

Kuuskraa et a1. 1978. "Vast Potential Held by Four 'Unconventional' Gas Sources." $0 i 1$ and Gas Journa 1, 76:48. 


\section{REFERENCES (contd)}

Leutkehans, G. R., and J. Toman. 1976. In Proceedings of the Symposium on Stimulation of Low Permeability Reservoirs, p. 28, Green Center Colorado School of Mines, Golden Colorado.

Myers, P. S. et a1. 1970. "Nation's Cost/Benefit Ratio Weighs Heavily on Auto Emissions." SAE Journal.

National Interim Drinking Water Regulations. 1976. U.S. Environmental Protection Agency, Office of Water Supply, Washington, DC.

National Safety Council. 1977. Accident Facts 1977. Chicago, IL.

Natural Gas Policy Act of 1978 (NGPA). 1978. Public Law 95-621.

Noise and You: The ABC's of Hearing Conservation. 1978. Channing L. Bite Co., Greenfield, MA.

Pakisen, L. C. et a1. 1969. "Earthquake Predictions and Control." Science 166: 1467-1474.

Randolph, P. L. 1976. "MHF Research in the Green River Basin." In Proceedings of the Sumposium on Stimulation of Low Permeability Reservoirs, p. 139, Green Center Colorado School of Mines, Golden Colorado.

Sax, N. I. 1957. Dangerous Properties of Industrial Materials. Reinhold Publishing Corp., New York, NY.

Unconventional Gas Recovery (Enhanced Gas Recovery). October 1979. DOE/EDP0049, Department of Energy, Washington, DC.

Western Gas Sands Project Quarterly Basin Activities Report. 1978. Technical Report No. NV0/0655-05, C. K. GeoEnergy Corporation, Las Vegas, NV.

Williams, J. 1978. Regional Energy-Environment Data Book Rocky Mountain Region. Technical Report No. S-2: 78-3, LoS Alamos Scientific Laboratory, Los ATamos, NM. 
APPENDIX A

PETROLEUM FIELD TECHNOLOGY 


\section{APPENDIX A}

\section{PETROLEUM FIELD TECHNOLOGY (a)}

During its first half century, the American oil Industry found petroleum by the utilization of seasoned, practical oilmen who spent their lives in the oil field. It was not until the second decade of the 20th century that the petroleum technologies (geophysics, geology, and engineering) became important in finding and developing petroleum fields. These technologies for the location and exploitation of petroleum have been evolving ever since.

Petroleum exploration, discoveries, development, and production are scientifically and technically based functions which utilize the physical sciences, the earth sciences, and petroleum engineering. The exploration and initial drilling efforts combine the expertise of the geophysicist, geologist, and engineer. The development work is principally the job of the engineer, with assistance from the geologist and a very slight contribution from the geophysicist. Production and resource processing are tasks performed by the engineer. Thus, it may be seen that full cooperation among these three disciplines is required for maximum results.

Presented in this section, in a generic sense, are the numerous stages in the development and abandonment of a petroleum (gas) field. Not all the steps may be followed for each well within a field. The general steps in the finding and development of a petroleum resource are:

- exploration

- development

- production

- abandonment.

Table No. A.l presents a much more complete list of the different stages in the recovery of petroleum from reservoirs.

(a) Petroleum is used here as a generic term for any oil or gas field. Until a wildcat well is drilled and tested, it is not known whether it contains oil, gas, or both. Most "gas" wells produce some condensate (oil). 
TABLE A.1. Stages in the Recovery of Petroleum from Reservoirs

1. EXPLORATION

- Regionar Surveys

- Detailed Surveys

- Wildcat Drilling

2. FIELD DEVELOPMENT

- Reservoir Definition

- Planning Well Space and Location

- Installation of Treating Facilities

- Collection and Distribution Facilities

3. PRODUCTION

- Surface Facilities Maintenance

- We1r Maintenance

- Stimulation

4. ABANDONMENT

- Plug Wells (cement to surface) and Mark

- Remove Surface Facilities

- Recontour and Reseed We11 Sites and Lease Roads

\section{A. 1 EXPLORATION}

Exploration covers all of the techniques, including the drilling of wildcat wells which may be used in locating geologic traps that possibly contain petroleum accumulations. It includes geological examination of surface features and the numerous geophysical methods of finding structures deep underground.

\section{A.1.1 Regional Surveys}

Regional exploration surveys employ passive techniques. Airborne instruments are used to measure and map abnormalities in both the earth's magnetic field and gravitational field. Areal surveys are also used to map surface features which may be indicative of underground features. Another important technique used in finding petroleum is locating and identifying hydrocarbons 
that seep into the atmosphere. Both gas and oil deposits have been located via hydrocarbon seeps.

\section{A.1.2 Detailed Surveys}

When regional surveys indicate that promising features are present, more detailed surveys are conducted. The most important technique is threedimensional seismic mapping.

Seismic data are collected by sending sound waves into the ground. These sound waves are, in turn, reflected and refracted by the subsurface geologic strata and are recorded on the surface.

The most common technique used to generate sound waves has been exploding dynamite or some other type of explosive material. However, newer and less environmentally destructive methods are available that use fast, highly efficient gas exploders, vibrators, and air guns.

Seismic data are interpreted through the use of very sophisticated computer programs. These seismic maps show the geologic nature of each different type of subsurface bed. In fact, they can even distinguish gas sands from those not containing gas. More important, they can locate stratigraphic, unconformity, and paleogeomorphic traps which may contain petroleum.

\section{A.1.3 Wildcat Drilling}

The previous techniques can only indicate structures which are potential petroleum traps. The actual location of a petroleum deposit and determination as to whether it contains commercial quantities of oil or gas require that a well be drilled and tested. Any well which is drilled into a locally new zone is considered to be a wildcat well.

Once a site for the wildcat well has been selected, permits to build a temporary road and approval of the complete drilling plan must be obtained. Since wildcats enter new zones, the danger of blowouts is greatest. The actual drilling operation is similar to drilling any well and will be discussed in the section on fieid development. 


\section{A.2 FIELD DEVELOPMENT}

The initial wells drilled into a zone previously identified by geological and/or geophysical exploration are termed wildcats. These wells are used to define the areal extent of the reservoir, the number of productive zones, their continuity, and the production capabilities. Once these factors have been found, the field will be developed on a regular surface spacing which is normally dictated by state and/or federal regulations. Common well spacings for gas wells are 160 acres/well, 320 acres/we11, and 640 acres/well. The number of wells drilled into a field during development is usually dependent on the depth of the producing zone, i.e., the deeper the zone, the fewer the wells that will be drilled.

Once the development for the field is selected, the locations of the drilling sites are known. A permit $(a)$ for all permanent roads to be constructed and for each well to be drilled must be obtained from the appropriate state and/or federal agency [USGS, BLM, BOIA (Bureau of Indian Affairs)]. This usually involves an actual inspection of the site. In addition, for a number of possible sites, a disclaimer that there are no important archeological sites present must be obtained.

\section{A.2.1 Site Preparation}

Once all the required permits and approvals have been obtained, work commences on clearing and leveling of the site. The leveled area may be from 1 to 5 acres, depending on the sizes of the drilling rig and stimulation job planned. A drill pit of approximately $1 / 2$ acre (included in the 1 to 5 -acre total) is also dug.

(a)Permits: Virtually every stage in the acquisition, exploration, and development of petroleum is licensed by some agency. On federal land, the BLM is in charge of leasing rights. Each drill site is inspected by the USGS. Each drilling program for each well is approved by the USGS. If the possibility of endangered species exists, the Wildlife Commission may be called in to help. State regulations are all handled through state oil and gas commissions or some equivalent agency. 
Some of these sites are on virtually level ground, while others may require extensive excavation, due to hilly locations. Some sites may be located on hills with more than a $30 \%$ slope, which may result in serious erosion problems. It is, however, important to remember that each and every site has been approved by the appropriate licensing agency.

\section{A.2.2 Drilling}

When a well is drilled, a certain zone is the target, whether it is a wildcat or development well. The mud program is selected before drilling is started. An appropriate government agency will have preset the depth for surface casing to be set. The well may be cored through all different zones of interest. Casing will usually be cemented across the producing interval. If problem zones are encountered, these will be isolated by the cementing of casing also.

\section{A.2.3 Completion}

Most gas wells are completed through casing which has been cemented in place. Once the cement is set, the well is completed by shooting shaped charges through the casing into the zones of interest. Upon completing the perforations, a small acid job may be run to clean up the well. Frequently, a larger hydraulic fracturing job will be run as well.

\section{A.2.4 Well Testing}

Once the well has been completed, it is normally tested. Each zone within the range is tested separately (isolating the zone by setting a packer between the zones). These tests will show the flow capacity, permeability, and may be used to estimate the overall reserves of each zone of interest.

\section{A.3 PRODUCTION}

During the production of a well, little happens externally to the well. On a regular schedule, a tanker will come to remove the condensate (assuming there is some). There may be a need to dispose of large quantities of produced water. In addition, most companies have a routine well-logging program where temperature surveys, radioactive logs and other logs are routinely run. 
If the flow rate of the well drops off, a new hydraulic fracturing job may be instigated. Again, fracturing may occur on an almost routine time interval.

\section{A.4 ABANDONMENT}

Once a well has reached the end of its productive life, it is abandoned. In a gas well, this occurs when the pressure has become too low to cause any gas to flow.

Abandonment procedures are always fixed by either federal and/or state agencies. In the West, the well is usually cemented to the surface. All surface facilities are removed. A marker is placed atop the cemented wall. (In the West, this is a standard 4-foot-high, 3-inch diameter pipe complete with the well name and location.) Once the abandonment has been completed, the site restoration occurs.

During site restoration, the area may need to be recontoured. Then the area must be reseeded with indigenous species. 
, 


\section{DISTRIBUTION}

No. of

Copies

OFFSITE

C. Atkinson

Department of Energy

Las Vegas, NV 89114
A. A. Churm
DOE Chicago Patent Group
9800 South Cass Avenue
Argonne, IL 60439

27 DOE Technical Information Center

Col. H. L. Arnold, Jr.

District Engineer

Portland District

Corps of Engineers

P.0. Box 2946

Portland, OR 97208

S. Ballou

Argonne National Laboratory

9700 South Cass Avenue

Argonne, IL 60439

J. Binanado

Bureau of Land Management

P.0. Box 30157

Billings, MT 59107

E. S. Burton

DOE Resource Applications and Evaluation

Washington, DC 20545

R. L. Butenhoff

DOE Office of Environmental

Research

Washington, DC 20545
No. of

Copies

J. Calder III

ARCO

1860 Lincoln Street Suite 501

Denver, CO 80295

R. C. Cluson

DOE Assistant Secretary

for Environment

Washington, DC 20545

L. E. Coate

U.S. Environmental Protection Agency

1200 Sixth Avenue

Seattle, WA 98101

J. A. Coleman

DOE Office of Technology Impacts

Washington, DC 20545

H. G. Curtis

Public Power Council

P.0. Box 1307

Vancouver, WA 98660

L. A. D'Andrea

Resource Applications

Department of Energy

Washington, DC 20545

R. M. Davis

Oak Ridge National Laboratory

P.0. Box $X$

Oak Ridge, TN 37830

R. Doel1

U.S. Geological Survey

354 Middlefield Road

Menlo Park, CA 94025 
No. of

Copies

R. A. Duncan

Northwest Power Pool

920 S.W. Sixth Avenue Room 1210

Portland, OR 97204

C. W. Edington

DOE Office of Health and Environmental Research

Washington, DC 20545

H. C. Elmore

Pacific Northwest Utilities Conference Committee

P.0. Box 1231

Wenatchee, WA 98801

W. Esselman

Electric Power Research Institute

P.0. Box 10412

Palo Alto, CA 94304

W. 0. Forster

DOE Office of Environmental

Research

Washington, DC 20545

W. Fulkerson

Oak Ridge National Laboratory

P.0. Box $X$

Oak Ridge, TN 37830

A. J. Goldberg

DOE Office of Technology

Impacts

Washington, DC 20545

W. Gwillian

Morgantown Energy Technology

Center

Collins Ferry Road

Morgantown, WV 26505
No. of

Copies

T. Harris

DOE Office of Technology

Impacts

Washington, DC 20545

J. A. Hebert

Human Affairs

Research Centers

4000 ND 41 st Street

P.0. Box 5395

Seattle, WA 98105

L. Henning

Electric Power Research Institute

P.0. Box 10412

Palo Alto, CA 94304

L. J. Hoover

Argonnne National Laboratory

9700 South Cass Avenue

Argonne, IL 60439

J. Hoozen

Bonneville Power Administration

P.0. Box 3621

Portland, OR 97208

P. W. House

DOE Office of Technology

Impacts

Washington, DC 20545

J. Jaksch

Los Alamos Scientific Laboratory

University of California

P.0. Box 1663

Los Alamos, NM 87545

A. B. Joseph

DOE Office of Nuclear

Regulatory Research

Washington, DC 20555 
M. Katz

Bonneville Power Administration P.0. Box 3621

Portland, OR 97208

J. E. Kiley

Bonneville Power Administration

P.0. Box 3621

Portland, OR 97208

D. Layton

University of California

Lawrence Livermore Laboratory

P.0. Box 808

Livermore, CA 94550

D. J. Lewis

Pacific Northwest Utilities

Conference Committee

920 S.W. Sixth Avenue

Portland, OR 97204

R. K. Lohrding

Los Alamos Scientific Laboratory

P.0. Box 1663

University of California

Los Alamos, NM 87545

F. G. Lowman

DOE Office of Nuclear

Regulatory Research

Washington, DC 20555

J. Maher

DOE Office of Technology

Impacts

Washington, DC 20545

H. McCammon

DOE Office of Health and

Environmental Research

Washington, DC 20545

W. J. McCool

DOE Office of Environmental

Compliance and Overview

Washington, DC 20545
P. M. Meier

Building 475

Brookhaven National Laboratory

Upton, NY 11973

D. M. Monti

DOE Office of Technology

Impacts

Washington, DC 20545

W. D. Moore III, Drilling Editor

$0 i 1$ \& Gas Journal

1200 S. Post Oak Road

P.0. Box 1941

Houston, TX 77001

P. Moskowitz

Brookhaven National Laboratory

Upton, NY 11973

W. E. Mott

DOE Office of Environmental

Compliance and Overview

Washington, DC 20545

S. M. Nealey

Human Affairs Research Centers

4000 ND 41 st Street

P.0. Box 5395

Seattle, WA 98105

E. Neblet

DOE Federal Energy

Regulatory Commission

U.S. Custom House

San Francisco, CA 94111

Maj. Gen. W. E. Peel

Division Engineer

North Pacific Division

P.0. Box 2870

Portland, OR 97208

Col. J. A. Poteat, Jr.

District Engineer

Seattle District

Corps of Engineers

1519 Alaskan Way South

Seattle, WA 98134 
No. of

Copies

M. Reilly

DOE Division of Fossil Energy

Washington, DC 20545

Col. G. R. Robertson

District Engineer

Alaska District

Corps of Engineers

P.0. Box 7002

Anchorage, AK 99510

J. B. Robertson

DOE, Federa 1 Region $X$

Federal Building, Room 1992

915 Second Avenue

Seattle, WA 98174

G. J. Rotariu

DOE Office of Technology

Impacts

Washington, DC 20545

A. Rudo Tph

Battelle Memorial Institute

505 King Avenue

Columbus, $\mathrm{OH} 43201$

M. Savitz

DOE Office of Conservation and Solar Energy

Washington, DC 20545

R. D. Shut 1

DOE Office of Technology

Impacts

Washington, DC 20545

W. E. Siri

University of California

Lawrence Berkeley Laboratory

Berkeley, CA 94720

D. H. Slade

DOE Office of Environmental

Research

Washington, DC 20545
No. of

Copies

E. Swenson

Resource Applications

Department of Energy

Washington, DC 20545

J. Swinebroad

DOE Office of Environmental Research

Washington, DC 20545

R. Uhler

Electric Power Research Institute

P.0. Box 10412

Palo Alto, CA 94304

R. J. Vissia

Bureau of Reclamation

Federal Building

550 West Fort Street

Boise, ID 83724

Henry F. Walter

DOE/ESED

M/S EV-132-E-201

Washington, DC 20545

B. W. Wachholz

DOE Office of Technology

Impacts

Washington, DC 20545

C. H. Watkins

Bonneville Power Administration

P.0. Box 3621

Portland, OR 97208

E. R. Williams

DOE Office of Technology Impacts

Washington, DC 20545

B. Wise

Morgantown Energy Technology Center

Morgantown, WV 26505 
No. of

Copies

R. W. Wood

DOE Office of Environmental

Research

Washington, DC 20545

T. York

Resource Applications

Department of Energy

Washington, DC 20545

\section{ONSITE}

DOE Richland Operations Office

H. E. Ranson

Rockwell Hanford Company

T. J. McLaughl in

Pacific Northwest Laboratory

W. J. Bair

N. M. Burleigh

C. E. Cowan

D. L. Hessel (10)

R. C. Lijkala

J. W. Litchfield

I. S. Levy

S. Marks

R. E. Rhoads

E. F. Riedel (5)

E. C. Watson

L. D. Williams

Publishing Coordination (2)

Technical Information Files (5) 
